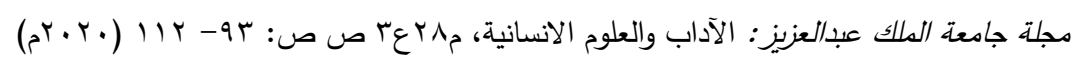

\title{
موقف الإمام ابن حزم الأندلسي من شبهة تحريف القرآن الكريم عند الثيعة
}

\author{
فهز بن محمد بن عبدالرحمن القرشي \\ أستاذ العتيدة المشارك بقسم العقيلة

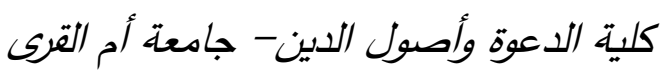

مستخلص. موقف الإمام ابن حزم الأندلسي من شبهة تحريف القرآن الكريم عند الثيعة دارت هذه الدراسة حول

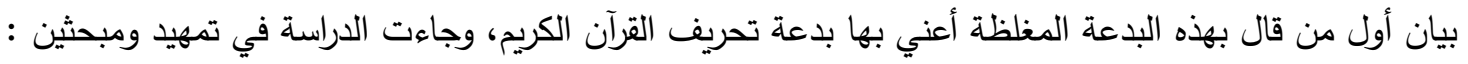
التمهيد: تم التعريف فيه بابن حزم والثيعة ومفهوم الثيعة عنده. والمبحث الأول: نشأة التشيع وأسبابه عند ابن حزم. والمبحث الثاني: موقف ابن حزم من شبهة تحريف القرآن الكريم.

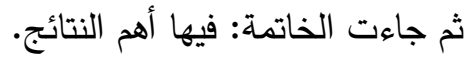

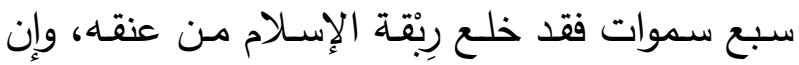

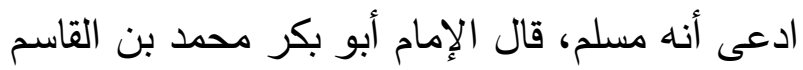

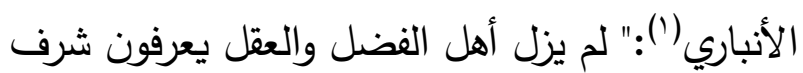

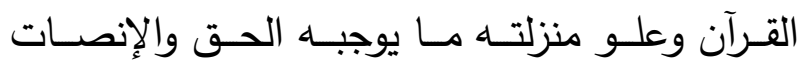
والديانة وينفون عنه قول المبطلين وتمويـه الملحدين وتحريف الزائغين، حتى نبخ في زماننا هذا زائع عن

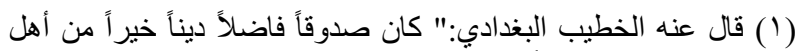

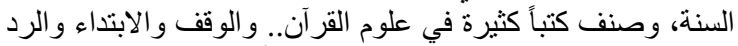

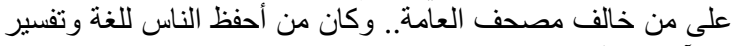

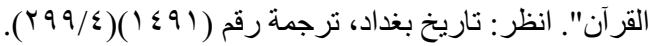

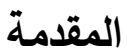

إن الحمد الله، نحمده ونستعينه ونستغفره، ونعوذ بالله

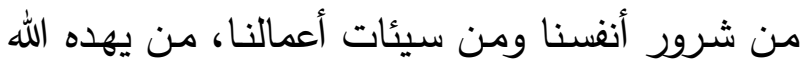

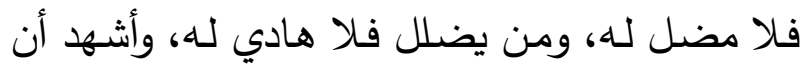

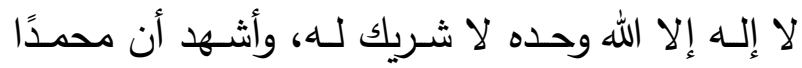

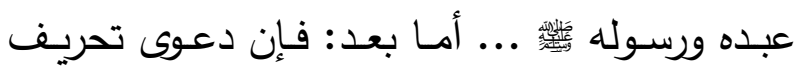
القرآن الكريم من الدعاوى الباطلة التي حاول الترويج

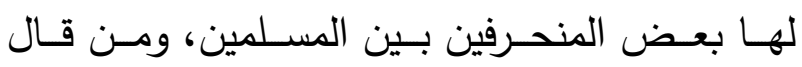
بتحريف القرآن الذي تكفل الله تعالى بحفظه من فوق لـن 
يعلى(0)، وأبو الثناء الألوسي(")، وموسى جار الله(Y)،

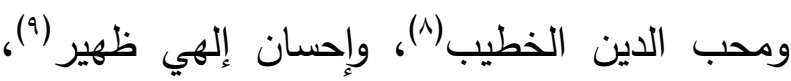

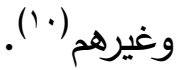
وقد انبرى للرد عليهم أعلام الأمة وتصدوا لهذه

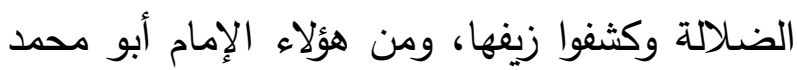
بن حزم الأندلسي (ت عليه، وسيكون هذا البحث كاشفًا لموقفه رحمه الله من هذه المقالة الشنيعة، والدعوى الكاذبة، أما عن لهن

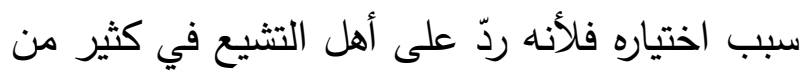

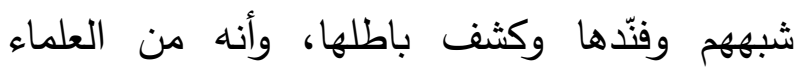

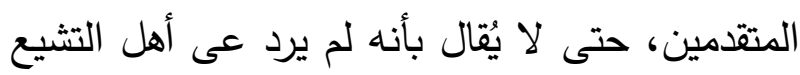

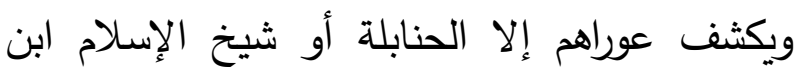
تيمية رحمه الله. وأما بالنسبة للنطاق البحث فسيكون

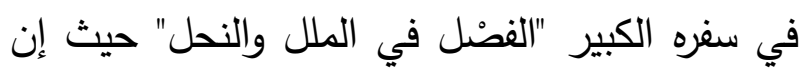
غالب ردوده على الثيعة في هذا السفر العظيم. وقد جاء البحث في مقدمة وتمهيد ومبحثين وخاتمة، كاللآتي: المقدمة: بينت فيها بداية هذه البدعة وأول من قال بها. التمهيد: عرفت فيه بابن حزم والثيعة ومفهوم الثيعة عiده

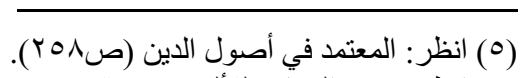

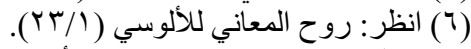

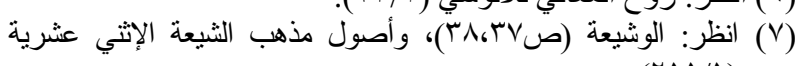
( (Y) $1 / 1)$

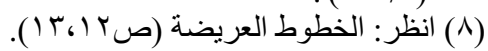

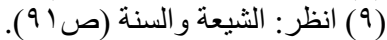

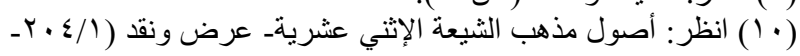

الملـة(') وهجم علـى الأمسة بمـا يحساول بـه إبطـال

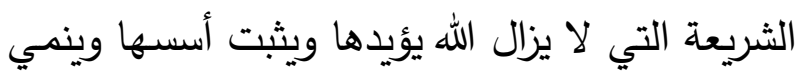

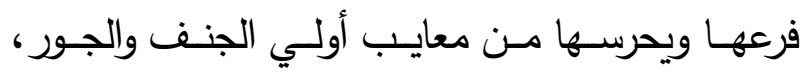

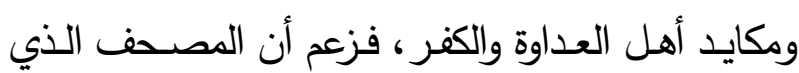

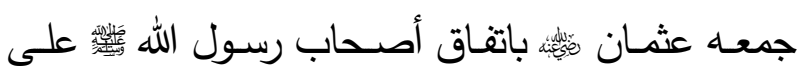
تصويبه فيما فعل لا يشتمل على جميع القرآن، إذ كان بان قد سقط منه خمسمائة حرف... فادعى هذا الإنسان أنه لـاني سقط على أهل الإسلام من القرآن (وما كان الله ليهلكها

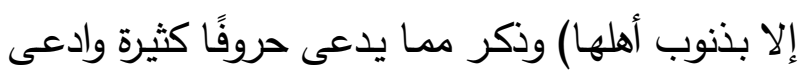

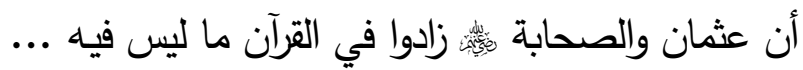

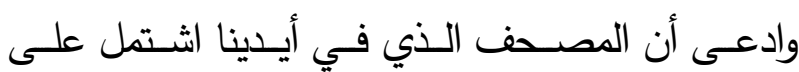
تصحيف حروف مفسدة مغيرة..." (؟). فهذا النص يدل على أن الأمة الإسلامية لا عهد لها لهات

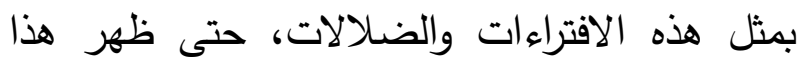
الثيعي الزائغ عن الملة هشام بن الحكم. وبعد هذا الزائغ الضال انتشرت هذه المقالة الثنيعة في أهل التشيع، وأثار إلى ذلك غير واحد من العلماء منهم

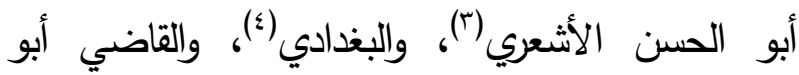

(1) أثشار "الملطي" في كتابه "التتبيه والرد" ص عـ ع إلى أن هذا الزائخ

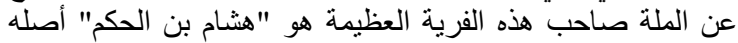

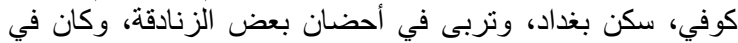

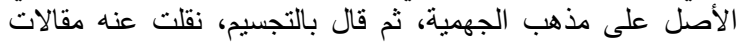

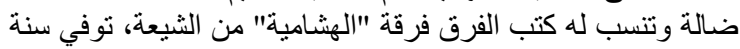

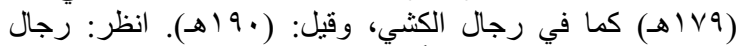

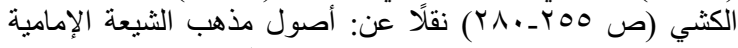

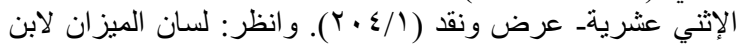

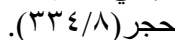

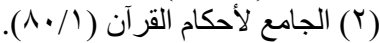

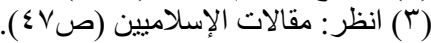

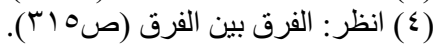


مالك وغيره، وانصـرف إلى العلم والتأليف يستتبط الأحكام من الكتاب والسنة(r). كان حافظـاً عالمـاً بعلـوم الحـديث وفقهـه، مسـتنبطاً للأحكام مسن الكتاب والسـنة، متفنتًا في علوم جمـة عاملاً بعلمه، زاهدًا في الدنيا بعد الرياسـة التي كانت

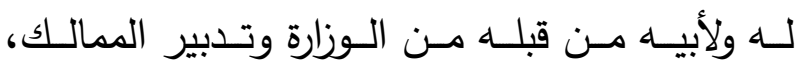
متواضعًا ذا فضـائل جمـة، وتواليف كثيرة في كل ما تحقق بـه في العلـوم، وجمـع مسن الكتب في علم الحديث والمصـنفات والمسـندات شـينًا كثيـرًا، وســع سـماعًا جمًا، كـان أبـوه وزيـرًا في الدولـة العامريـة بالأنـدلس، وولي هـو وزارة بعـض حكـام بنـي أميـة بالأندلس، ثم ترك ذلك. مؤلفاته : - من

كان ابن حزم مؤرخ متثـعب العلوم، واسـع المعرفـة، ملم بأخبار الأندلس بشكل دقيق، وقد ترك العديد من المؤلفات، ذكر الإمـام الذهبي أنه كان" لأبي محمد

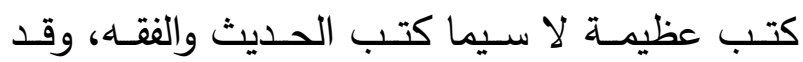
صـنف كتابًَا كبيرًا في فقـه الحديث سـماه "الإيصـال إلــى فهـم كتـاب الخصــال الجامعـة لجمـل شـرائع الإسـلام والحلال والحرام والسنة والاجمـاع"، أورد فيه أقوال الصـحابة فمَنْ بعدهم والحجـة لكل قول وهـو كبير جدًا، ولـه كتاب الإحكام في أصـول الأحكام مجلـدان، وكتـاب المجلـى فـي الفقــه علـى مذهبــه

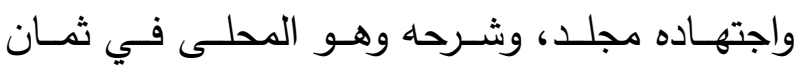
مجلدات، وكتـاب الفصـل في الملـل والنحـل ثـلاث

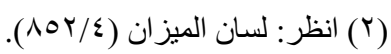

المبحث الأول: نشأة التشيع وأسبابه عند ابن حزم. المبحث الثاني: موقف ابن حزم من شبهة تحريف القرآن الكربح. الخاتمة: وفيها أهم النتائج. التمهيد

التعريف بابن حزم والثيعة ومفهوم الثيعة عند ابن حزم والحديث في هذا التمهيد عن ثلاثة أمور على النحو

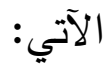
ـ التعريف بابن حزم.

هو أبو محمد علي بن أحمد بن سعيد بن حزم بن غالب بن صالح بن خلف بن معدان بن سفيان بن يزيــد الظـاهري، عـالم الأندلس في عصـره، وينتهي نسبه إلى يزيد جده الأعلى، فارسيُ أسلم بعد أن كان نصرانيًا، نسبته للأمويين نسبة موالاة؛ إذ كان جده

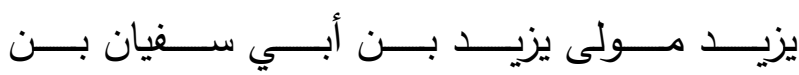
حرب بن أمية اخو معاوية ('). وُلا ابن حزم- كما ذكر هو عن نفسـ- بقرطبة سنة أربـع وثــانين وثـلاث مائـة، نشـأ في نعمـة ورياسـة

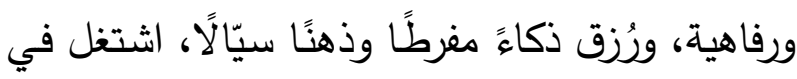

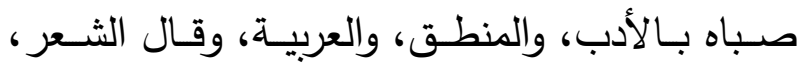
وترسـل(r)، ثم أقبـل على العلم، فقرأ الموطأ للإمـام

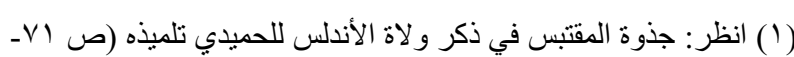

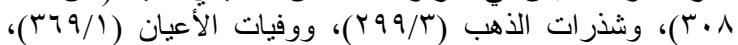

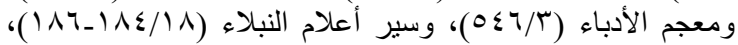

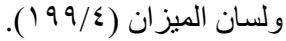

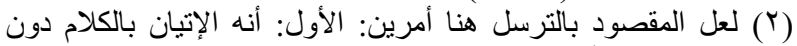

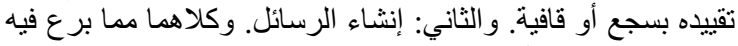

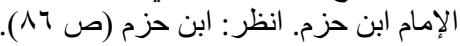


العرب"، وكتاب "نقط العروس"، وكتاب "حجة الوداع الذي أشار إليه في كتابه طوق الحمامة(^). والإمـام ابن حزم يعتمد في مؤلفاته وردوده على شبهات

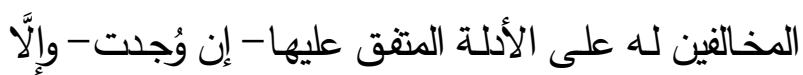

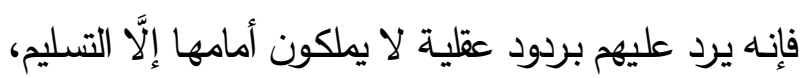

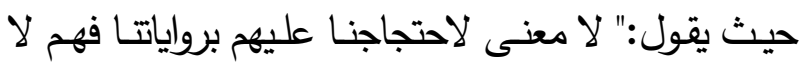

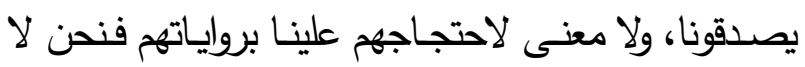

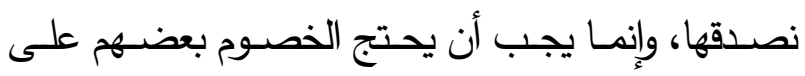

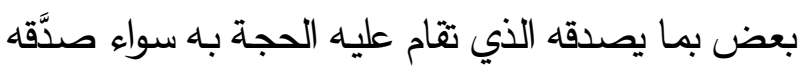

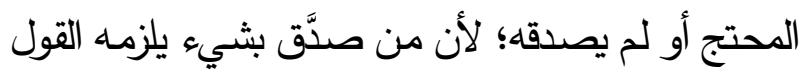

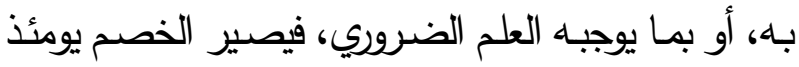

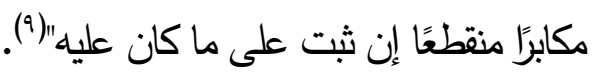

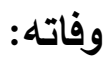

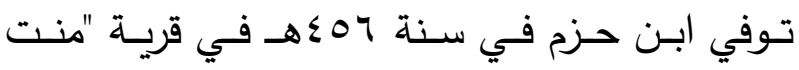

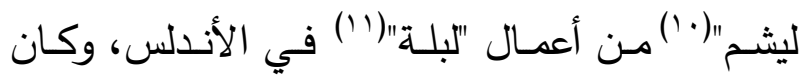

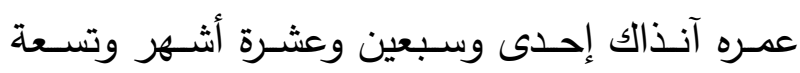
وعشرين يومًا (r').

r. التعريف بالثيعة لغة واصطلاحًا

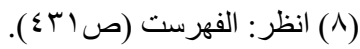

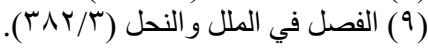

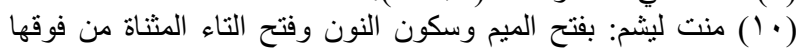

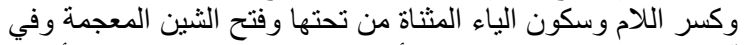
آخرها ميم وهي قرية من أعمال لبلة. انظر: وفيات لانيات الأعيان

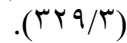

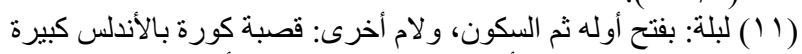

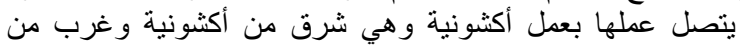

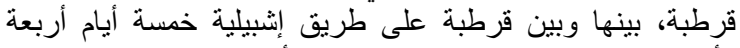

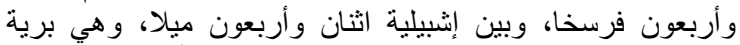

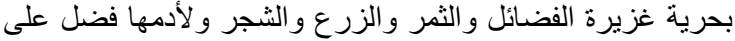

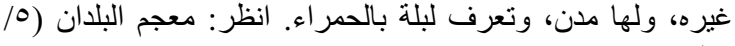

. (1.

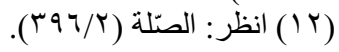

مجلدات، وكتـاب إظهـار تبـديل اليهـود والنصـارى للكتابين التوراة والإنجيل، وكتاب التقريب لحد المنطق والمدخل إليه بألفاظ أهل العلم لا بألفاظ أهل الفلسفة ولته

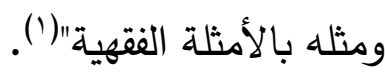
أما بالنسبة لمؤلفاته في العقيدة، فمنها:

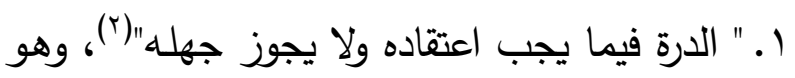

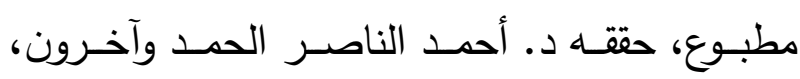

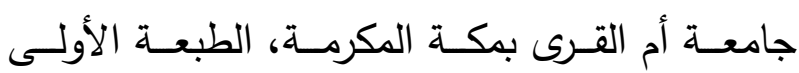
1 • أ اهـ، مطبعة المدني- القاهرة. r. " "كتاب في أسماء الله"(").

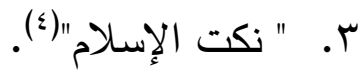
ع. " " مسألة الإيمان" (o). ه. " الرسالة الصمادحيّة في الوعد والوعيد"(؟).

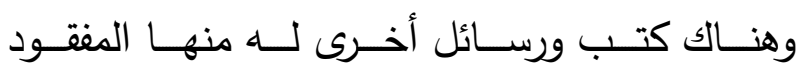

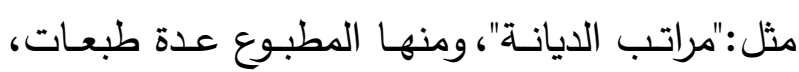
مثل :" الفصْل في الملل والنحل" "(v). كمـا ذكر ابـن النديم جملــة مـن كتبه، التي أبرزهـا

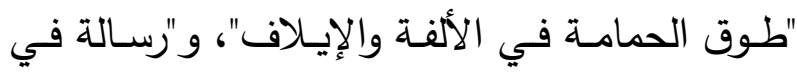

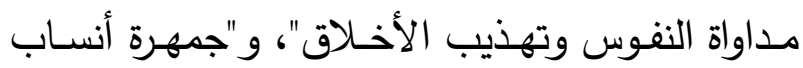

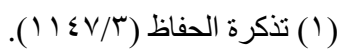

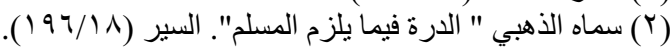

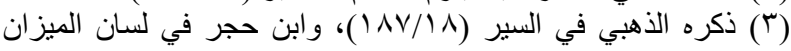

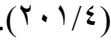

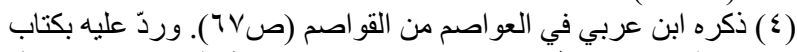

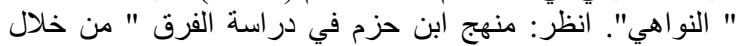

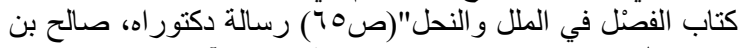

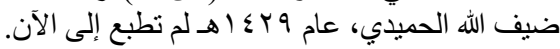

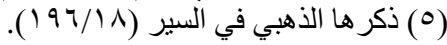

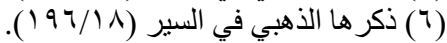

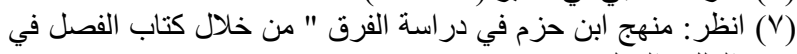
الملل و النحل" (صن آج). 
رضـي الله تعـالى عنهمـا-، وغـلاة غلاتهـم ضــاَّله

يكفرون الثيخين، ومنهم من يرتقي إلى الزندقة"(•). وإذا تأملنا في القرآن الكريم والسنة المطهرة، نجد أن مادة (شيع) وردت في القرآن الكريم في اثني عشر موضعًا(־)، وذكر ابن الجوزي معانيها حيث قال:

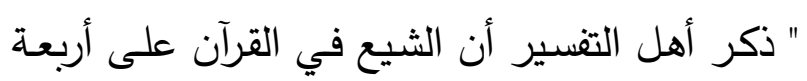
أوجها:

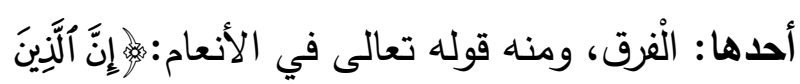

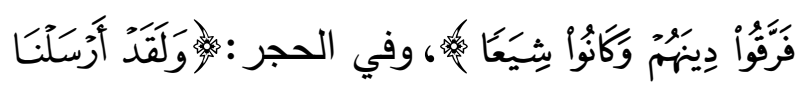

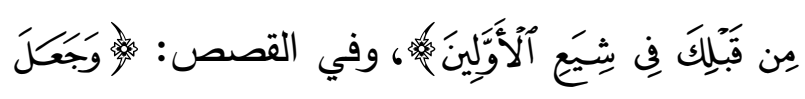

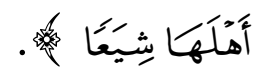
الثــاني: الأهـل والنسـبـ، ومنــه قولـهـ تعـالى فـي القصص: أهله) في النسب إلى بني إسرائيل. الثالث: أهل الملة، ومنه قوله تعالى في مريم:

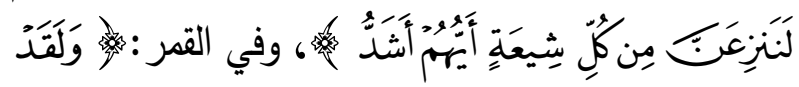

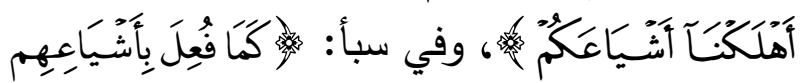

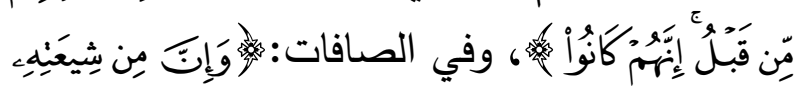

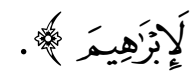
الرابع: الأهواء المختلفة، ومنه قوله تعالى في الأنعام:

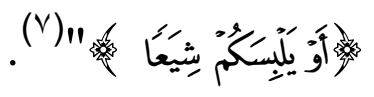

الدكتور : ناصر بن عبدالله القفاري.

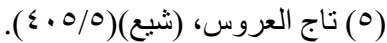

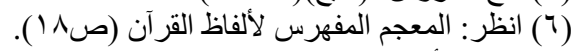

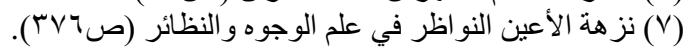

الثـيعة في كتـب اللغــة تعنـي الأتبـاع والأنصـار ، والتشيع معنـاه: المتابعـة والمناصـرة، لكن كتب اللغـة قد تتعرض أحيانًا إلى ذكر التعريف الاصطلاحي

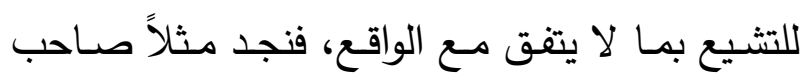
كتاب" تهذيب اللغـة" يعرّف الثـيعة بحسب مـا شـاع واشتهر عنهم في زمنه، فيقول:" الشيعة: قوم يهوون

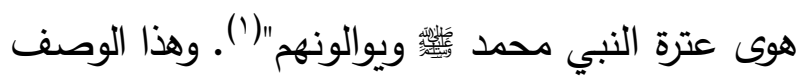
الذي ذكره الإمام الأزهري إن صدق على من كانوا في زمنها إلا أنه أبعد ما يكون عن الطائفة الاثتي عشرية التي يطلق عليها لقب الثيعة في عصرنا الحاضر ، فهم يعادون آل البيت، ويكغرون جملة منهم. ويقول ابن منظور :" قد غلب هذا الاسـم على من يتولى عليًا وأهل بيته"(r). وقـال الزبيدي:" قد غلب هذا الاسـم على كل مـن

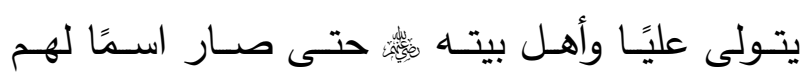
خاصًا، فإذا قيل: فلان من الشيعة، عُرف أنه منهم، وفي مذهب الثيعة كذا، أي عندهم. أصل ذلك من المشـايعة، وهي المطاوعة والمتابعة، قال الحافظ(ّ):

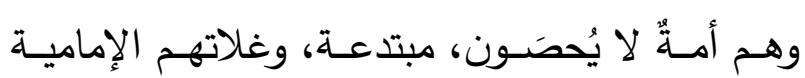

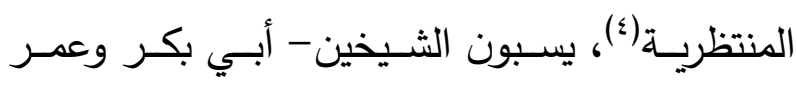

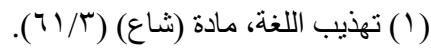

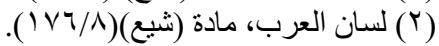

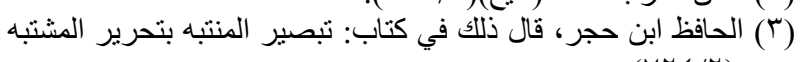
( $(Y Y \leq / Y)$

( ) المراد بالمنتظرية: الذين ينتظرون منذ أكثر من ألف ومئة وسبعين

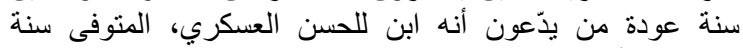

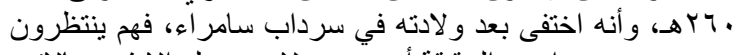

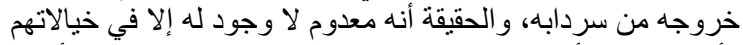

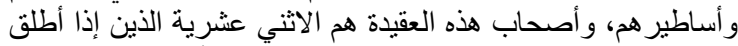

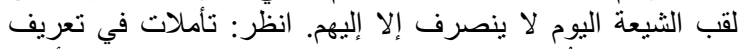

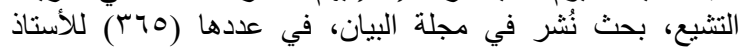


الثاني: القول بأحقيته بالإمامة. الثالث: القول باختصاص الإمامة به وولده من بعده. وعلى ذلك يدور وصف التثيع وجودًا وعدمًا (؛). وعرّفهم الشهرستاني بقوله:" الثيعة هم الذين شايعوا

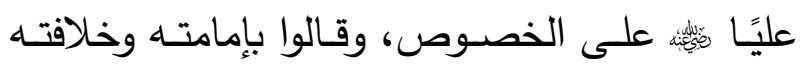

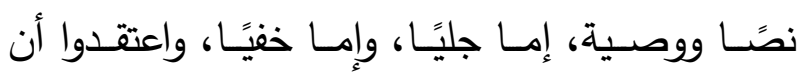

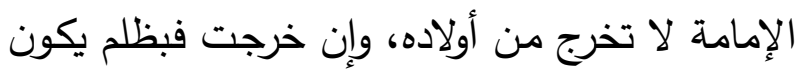
من غيره، أو بتقية من عنده. وقالوا: ليست الإمامة قضية مصلحية تناط باختئ عندهار العامـة وينتصـب الإمـام بنصـبهم، بـل هـي قضـية الامهية

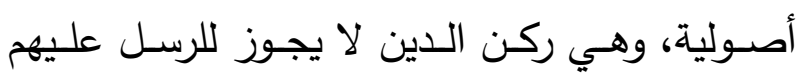

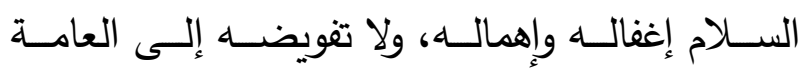
وإرساله.

ويجمعهم القول بوجوب التعيين والتتصيص، وثبوت عصمة الأنبياء والأئمة وجوباً عن الكبائر والصغائر .

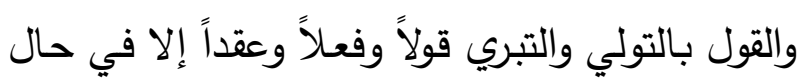

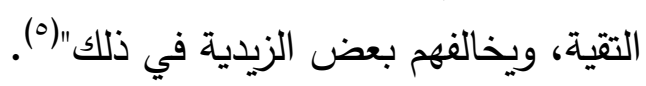

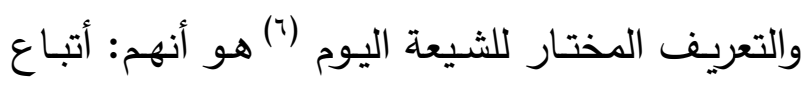

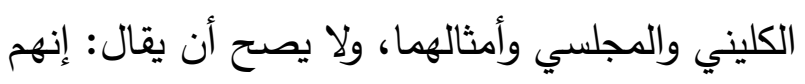
أتباع أهل البيت أصلًا (v) المبحث الأول

(๕) انظر: تأملات في تعريف التشيع، بحث نُشر في مجلة البيان، في عددها (10) (ب) (ب).

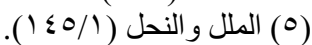

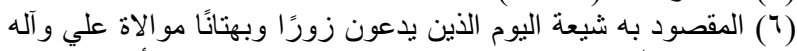
رضي الله عنهم، ولا يعني هذا عدم صحة تعاريف الأئمة السابقين

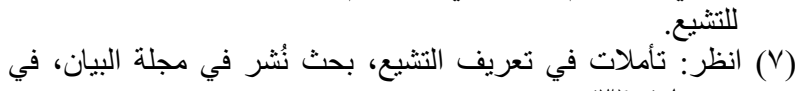

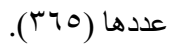

وقد أشار العلامة ابن القيم إلى أن لفظ الثيعة والأثياع غالبًا ما يستعمل في الذم، كما في مثل الثل

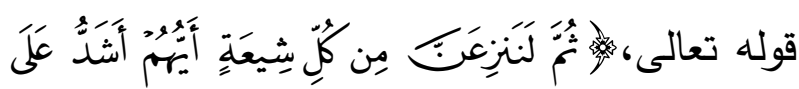

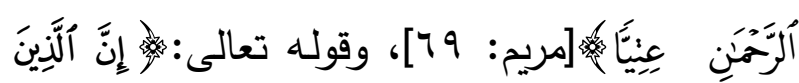

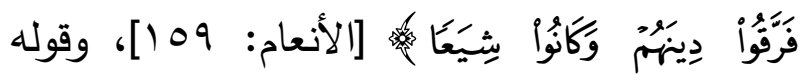

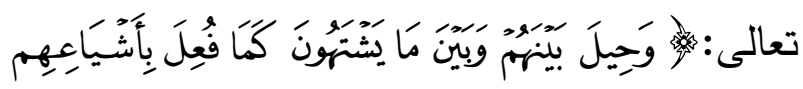

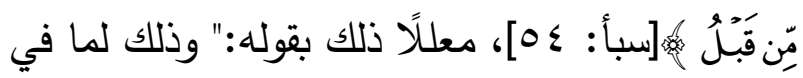
لفظ الثيعة من الشياع والإشاعة التي هي ضدل

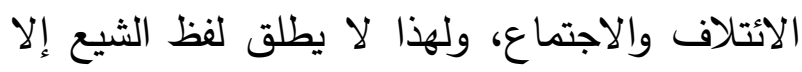

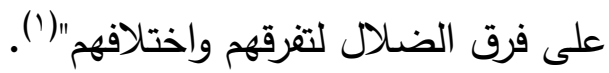
تعريف الشيعة اصطلاحًا: تعـرّض كثيـر مـن علمــاء المقــالات لتعريـف الثـيعة

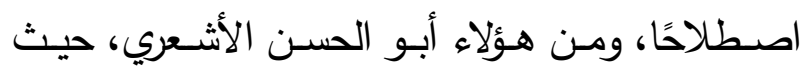

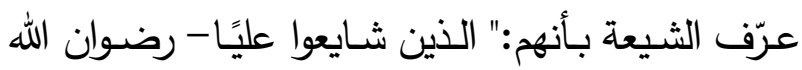

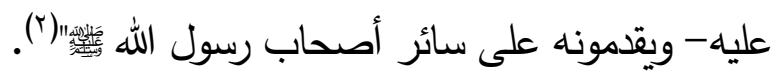

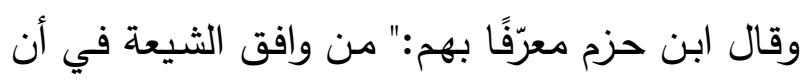

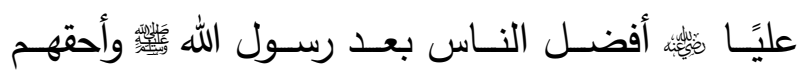
بالإمامـة وولده من بعده فهو شيعي، وإن خالفهم فيما

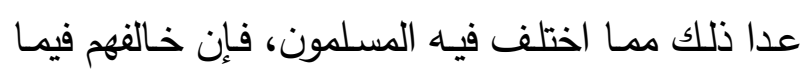
ذكرنا فليس شيعيًا"("). فابن حزم يرى أن التشيع يقوم على ثلاثة أسس:

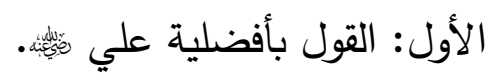


الملقب "خذاشـا"(0)، و "أبو مسلم السـراج"(؟)، فرأوا أن كيده على الحيلـة أنجـع، فأظهر قوم منهم الإسـلام واستمالوا أهل التشيع بإظهار محبة أهل البيت أعني

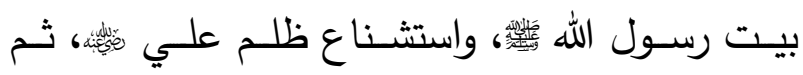
سلكوا بهم مسالك شتى حتى أخرجوهم عن الإسلام.

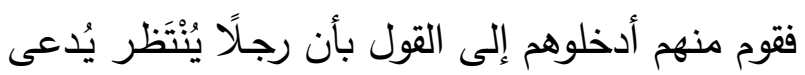

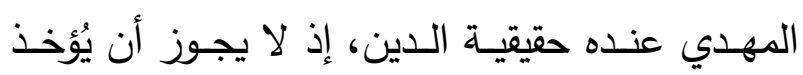
الدين من هؤلاء الكفار ، إذ نسبوا أصحاب رسول الله • وقوم خرجـوا إلى مـا ذكرنـا مـن نبـوة مـن ادعـوا إلـه النبوة، وقوم سلكوا بهم المسلك الذي ذكرنا من القول بـالحلول وسـقوط الثـرائع، وآخرون تلاعبـوا فـأوجبوا عليهم خمسـين صـلاة في كل يـوم وليلـة، وآخرون قالوا: بل هي سبع عشر صلاة في كل صـلاة خمسة عشـر ركعـة، وهـذا قـول "عبـد الله بـن عمـرو بـن الحارث الكندي" "(v)، قبل أن يصير خارجيًا صفريًا. وقد سلك هذا المسلك أيضًا "عبد الله بن سبأ الحميري"

الخرمية، كان ظهوره سنة (1 ـ أهـ) بناحية أذربيجان، يقول بإسقاط

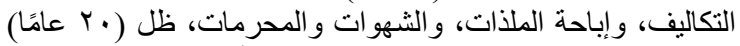

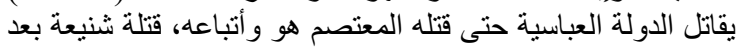

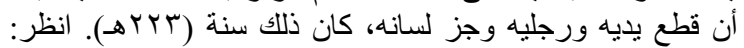

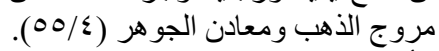

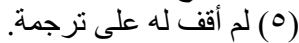

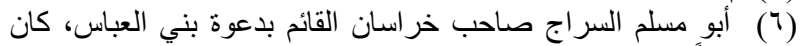

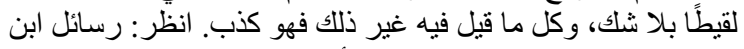

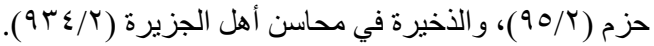

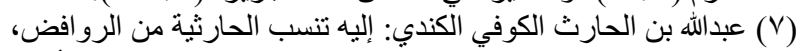

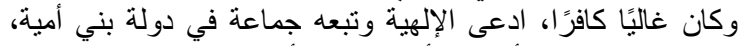

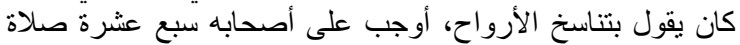

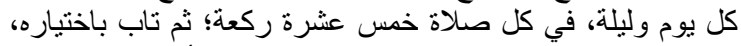

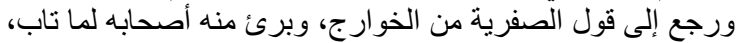

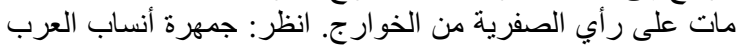

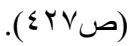

نشأة التشيع وأسبابه عند ابن حزم

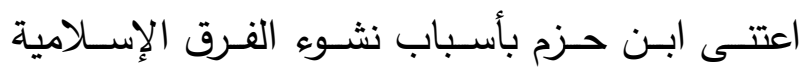
وظهورها، والبحث في أصولها، وذكر أسبابًا لنشأتها، ونظرًا لكون الدراسة عن موقفه من الثيعة، فسيكون

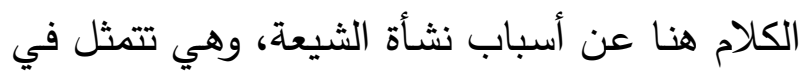

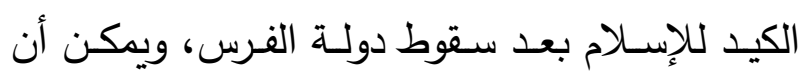

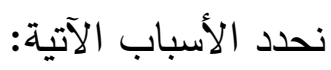
أولًا: الأسـباب السياسـية: بـيّن الإمـام ابـن حـزم دور

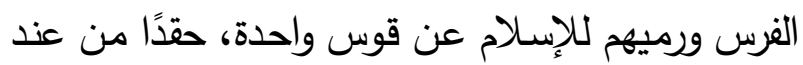
أنفسهم، حيث يقول:" والأصـل في أكثر خـروج هذه ونه

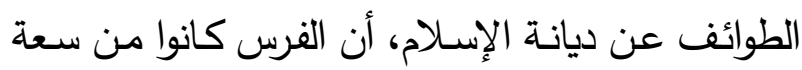

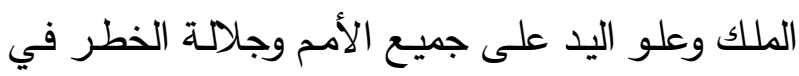
أنفسهم حتى إنهم كانوا يسمون أنفسهم الأحرار والأبناء،

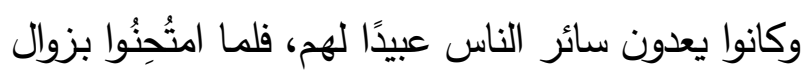
الدولة عنهم على أيدي العرب، وكانت العرب أقل الأمم

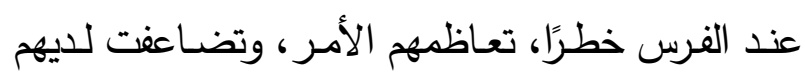

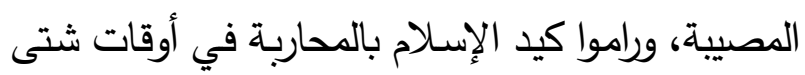

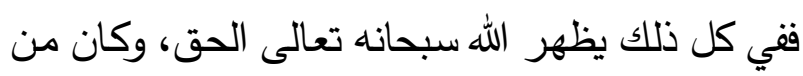

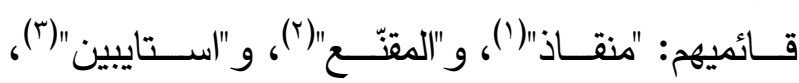

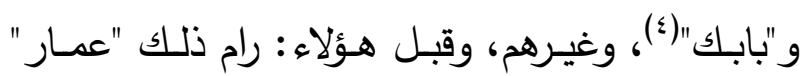

( (1) لم أقف له على ترجمة.

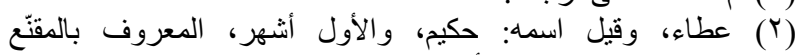

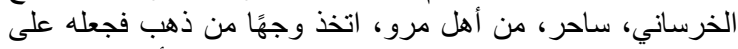

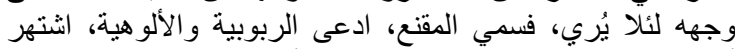

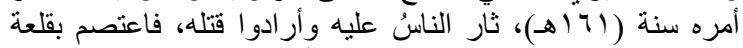

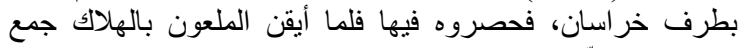

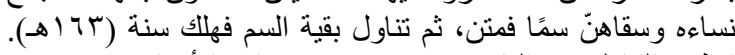

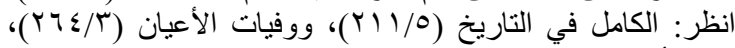

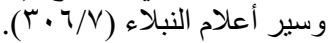

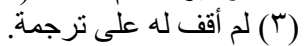
(צ) بابك الخرمي: رجل فل فارسي مجوسي الأصل، تتسب له فرقة 
لهم وسيلة وستارًا لاستمالة قوم من أهل الإسـلام إلى

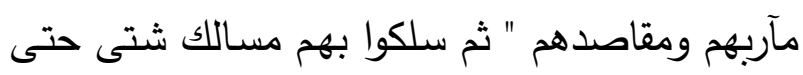

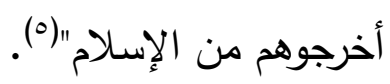

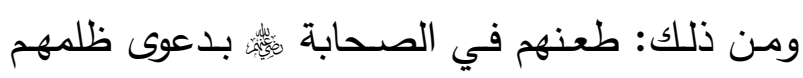
لعلي

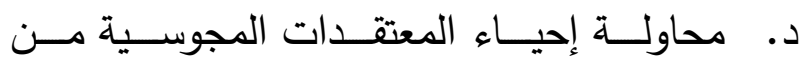

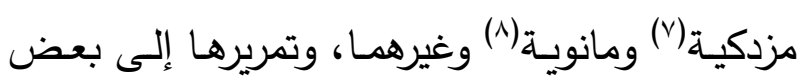
الفرق الإسـلامية مثل الإسماعيلية(9)، والقرامطة (') ')

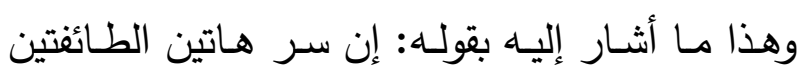

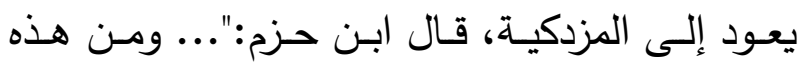
الأصول الملعونة حدثت الإسماعيلية والقرامطة وهما

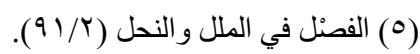

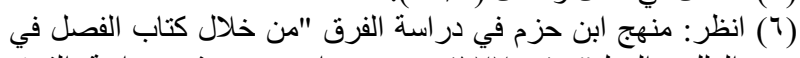

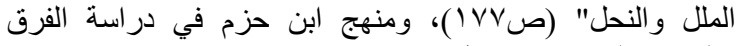

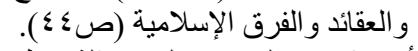

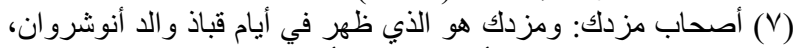

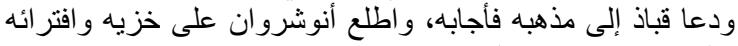

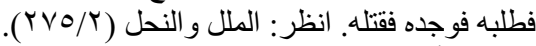

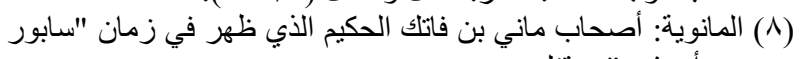
بن أردشير"، و وقتله

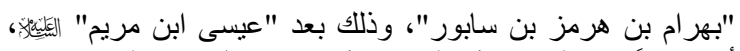

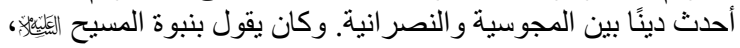

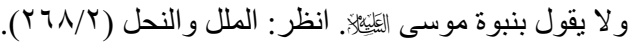

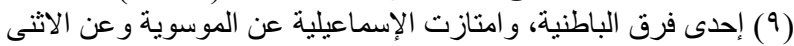

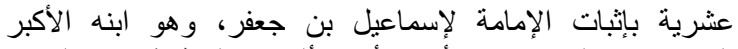

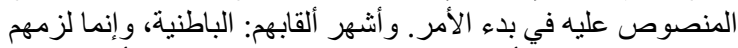

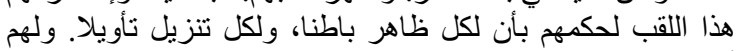

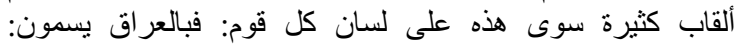

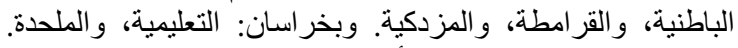

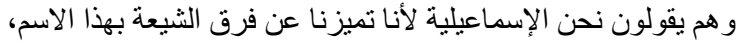

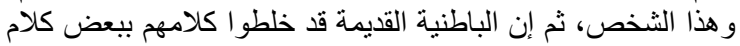

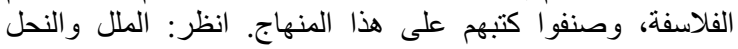
.(r.r-199/1)

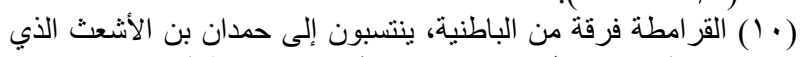

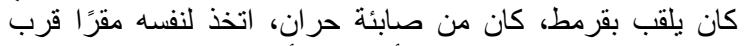

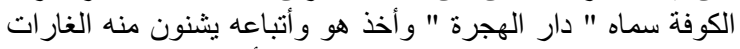

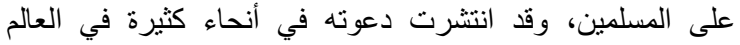

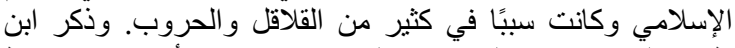

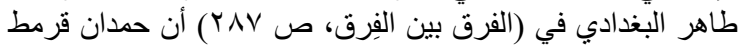

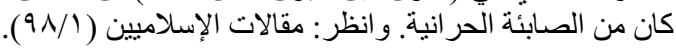

اليهودي(') فإنـه لعنه الله أظهر الإسـام؛ لكيد أهله، فهو

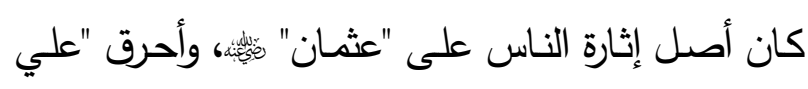
بن أبي طالب" مأئد منهم طوائف أعلنوا بإلهيته. ومن هذه الأصول الملعونة حشث الإسماعيلية والقرامطة

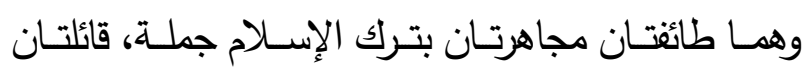
بالمجوسية المحضة..."( (؟). فـالفرس بـلا شـك سـبب مـن أسباب ظهـور الثـيعة

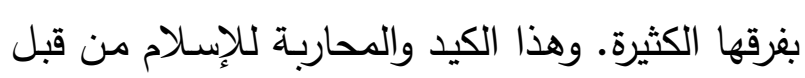
هؤلاء الفرس في غاية الوضوح، وقد ذكر ابن حزم

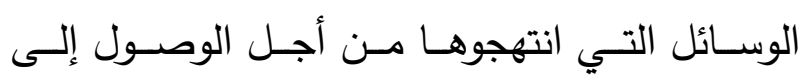

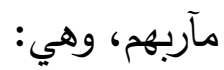
أ. التمرد والخروج عن السلطة المركزيـة الإسـلامية،

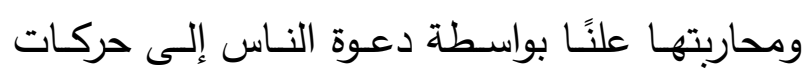

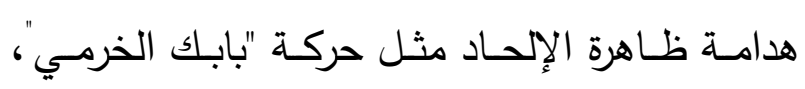
و "المقنّع"، وغيرهما"َ).

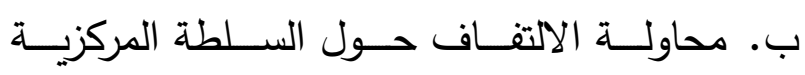

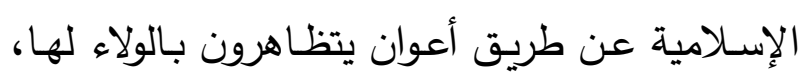

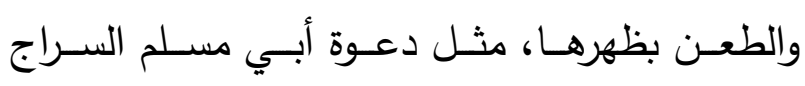

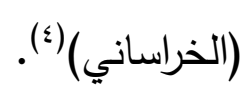

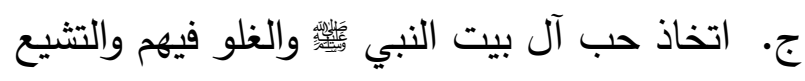

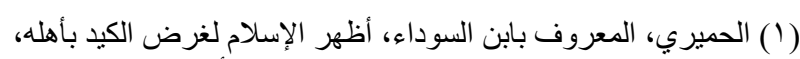

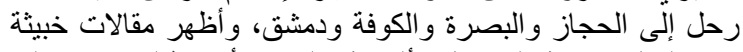

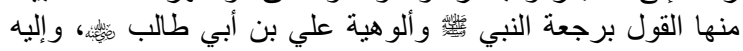

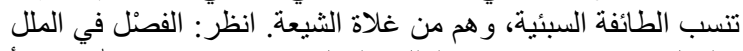

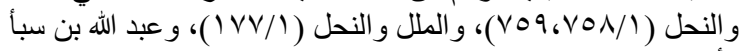

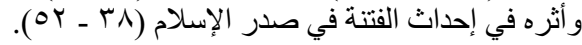

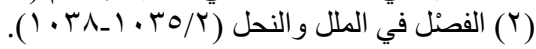

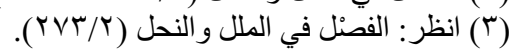

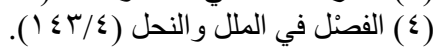




$$
\text { المبحث الثاني }
$$

موقف ابن حزم من شبهة تحريف القرآن الكريم شبهة تبديل الصحابة هوبة للقرآن الكريم القرآن الكريم هو المصدر الأول للتشريع الإسـلامي، التهي، وهو الكتاب الذي أنزله الله تعالى على نبيه محمد لئسي بلسـان عربي مبين، ويشتمل على تشريعات مجملة؛ وهـي معظم العبـادات، وأخـرى تفصـيلية؛ وهـي مـا يتعلـق بالقصــاص والحـدود والحـلال والحــرام فـي الأطعمة وقسمة الميراث ونحو ذلك، وقد حظي هذا الكتاب الكريم المصدر العظيم بعناية المولى سبحانه

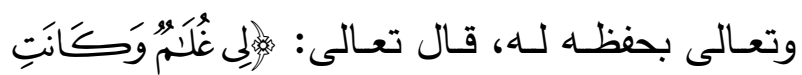

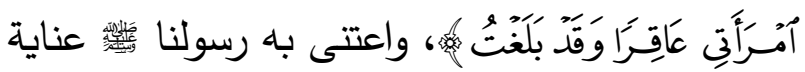

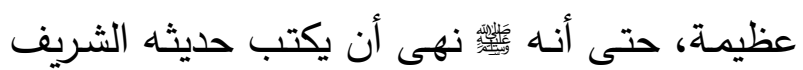

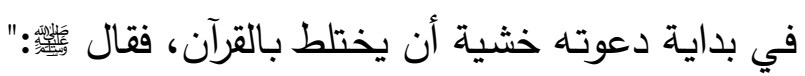
لا تكتبوا عني، ومن كتب عني غير القرآن فليمحه، وحدِّوا عني ولا حرج، ومن كذب عليَّ- قال همام: أحسبه قال: متعددًا - فليتبوأ مقعده من النار "(؟). ثم ودئ لمـا استقر الأمـر وزال خـوف اختلاط القرآن الكريم

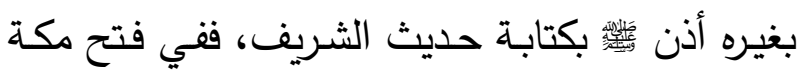

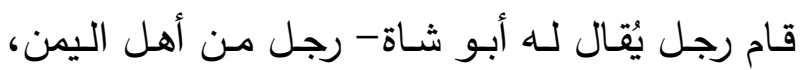

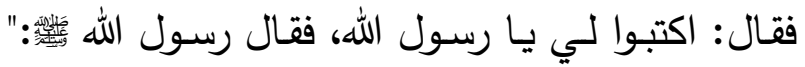

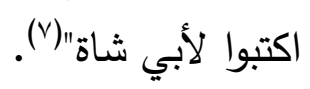

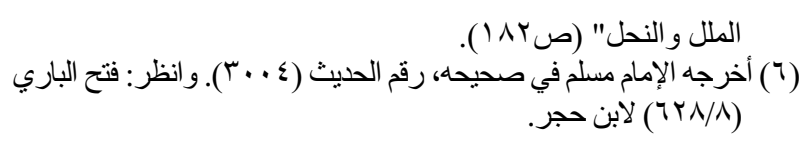
(V) أخرجه الإمام البخاري في صحيحه، رقم الدديث (ع (Y Y)، و الإمام
طائفتـان مجاهرتـان بتـرك الإسـلام جملـة، قائلتـان بالمجوسية المحضـة، ثم مذهب "مزدك الموبذ" الذي كان على عهد "أنو شـروان بـن قبـاذ" ملـك الفـرس، وكــان يقـول بوجـوب توسـي النـاس فـي النســاء

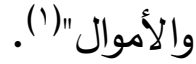
ثانيًا: الاستجابة لدعوات أهل السوء : من الأسباب المهــة التـي أدت إلى ظهـور الفـرق في نظر ابـن حزم، سبب ظهور الغلاة من الشيعة إلى كيد عبد الله بن سبأ اليهودي الذي تظـاهر بالإسـلام ليضـل مـن يسـطيع إضـالاله مـن المسـلمين (r)، قـال ابـن حزم:" وكان مبدؤها إجابـة مـن خذلـه الله تعـالى لـدعوة مـن

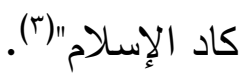
وخروج أكثر أتباعها عن الإسـلام، حيث قال:" فإن الـروافض ليسـوا مـن المسـمين إنمـا هـي فِرَق حدث أولها بعد موت النبي مبـدؤها إجابـة مـن خذلـه الله تعـالى لـدعوة مـن كـاد الإسـام وهي طائفـة تجري مجرى اليهود والنصـارى في الكذب والكفر ، وهي طوائف أشدهم غلوًا يقولون: بإلهيـة علي بـن أبـي طالب والآلهيـة جماعـة معسه، وأقلهم غلوًا يقولون: إن الثمس رُدت على علي بن أبي طالب مرتين...."(؛). ثالثًا: أثز الثقافات والعقائد الأجنبية؛؛ كما سبق من الأثر الفارسي واليهودي لعبدالله بن سبأ(ه).

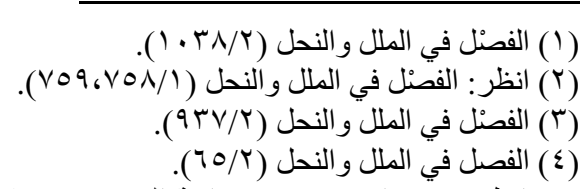
(0) انظر: منهج ابن حزم في دراسة الفرق "من خلال كتاب الفصل في 
أيستشنع منهم كذب يأتون بـه!! وكل من لم يزجره

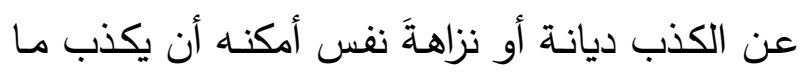

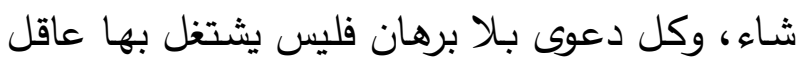

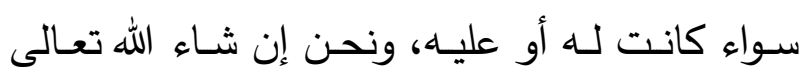
نأتي بالبرهان الواضح الفاضح لكذب الروافض فيما

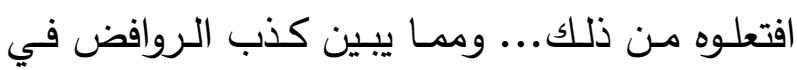

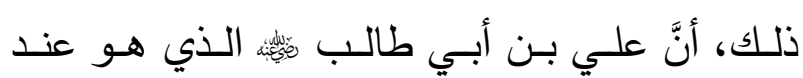

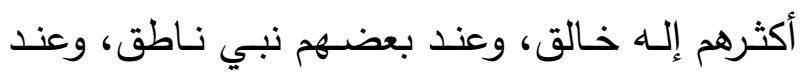

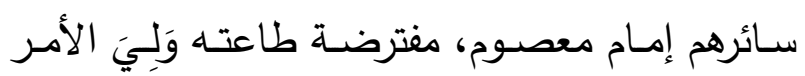

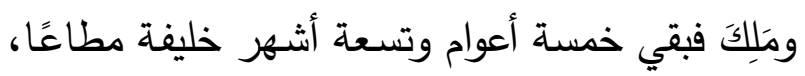

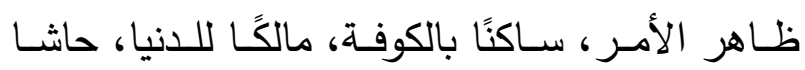

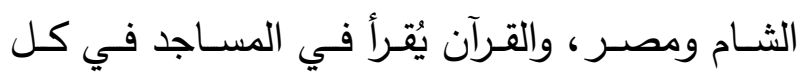

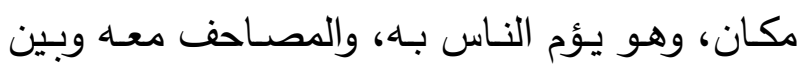

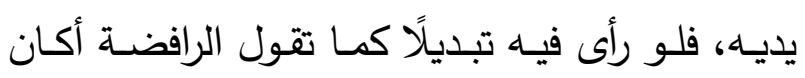
يُمِرَّهم على ذلك؟؟. ثم إلى ابنه الحسن الذي هو عندهم كأبيه فجرى على

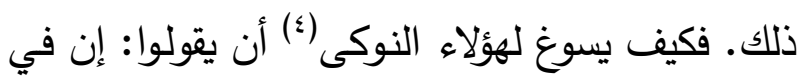

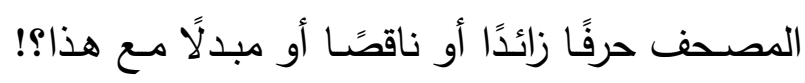

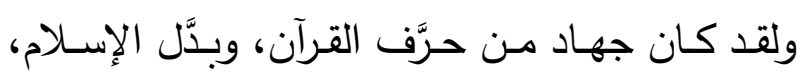

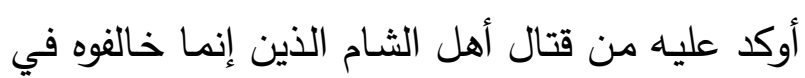

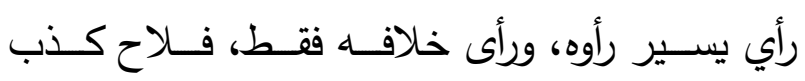

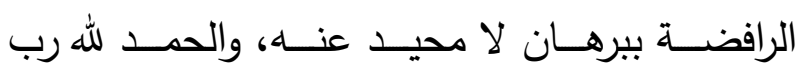
العالمين..." (0).

(§) النُوكُك، بالضم: الحمق. وتجمع على: النوكى. انظر: لسان العرب:

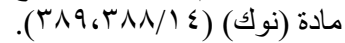

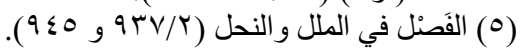

كمــا حظـي القـرآن الكـريم بعنايـة الرعيـل الأول مـن

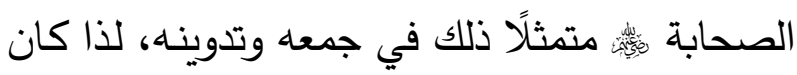

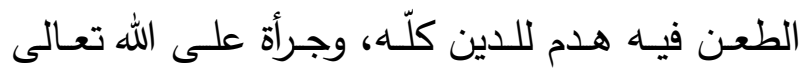

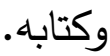
دعوى تبديل القرآن الكريخ قال ابن حزم:" فإن الروافض يزعمون أن أصحاب نبيكم بدلوا القرآن وأسقطوا منه وزادوا فيه" ('). والقول بتحريف القرآن الكريم من العقائد الثابتة عند الرافضـة، وقد ألف بعض أئمتهم في هذا كُتبًا، مثل من

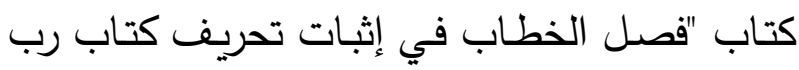
الأربـاب- عـرض ونقــ"، لــ: ميـرزا حسـين نـوري

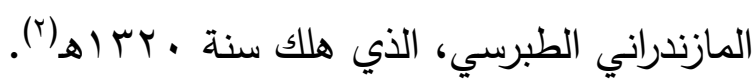
وقد رد عليهم ابن حزم بقوله:" وأما قولهم في دعوى الطئه

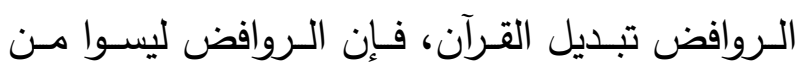

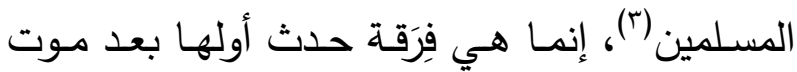

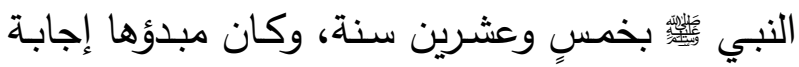

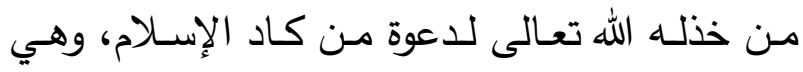

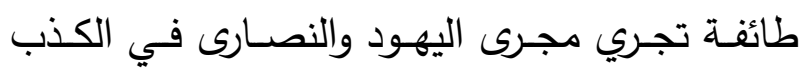
والكفر، وهـي طوائف أثـدهم غليوًا يقولـون: بإلهيـة

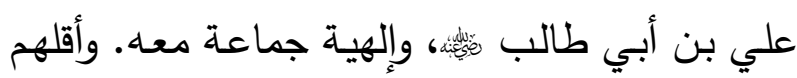

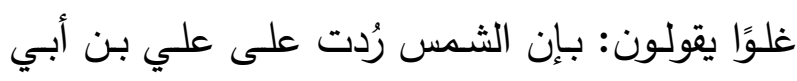

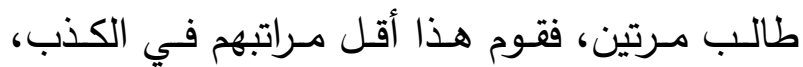

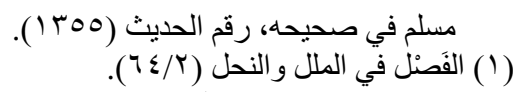

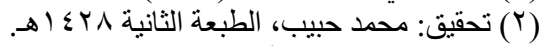

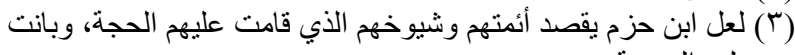
لهم المحجة. 
وأيضًا: فـإن طوائف مـن علمـائكم الذَين تعظمهون وتأخذون عنهم دينكم يقولون: إن عثمان بن عفن عنان

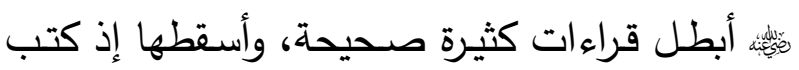
المصحف الذي جمعكم عليه، وعلى حرف واحد من الأحرف السبعة التي نزل بها القرآن عندكم؟!

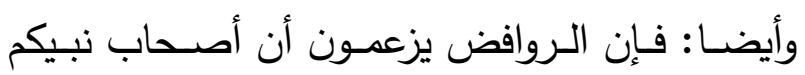
بدلوا القرآن، وأسقطوا منه، وزادوا فيه"("ن). ثم أجاب على شبهـهم هذه بقوله رحمه الله:" كل هذا لا متعلق لهم بشيء منه على ما نبين بما لا إشكال فيه عند أحد وبالله التوفيق. أما قولهج: إننا مختلفون في قراءة كتابنا فبعضنا يزيد حروفًا وبعضنًا يسقطها، فليس هذا اختلافًا بل هو اتفاق منا صحيح، لأن تلك الحروف وتلك القراءات كلها مُبلَّغ بنقل الكواف إلى رسول الله لـان أنها نزلت كلها عليه، فأي تلك القراءات قرأنـا فهي صحيحة، وهي محصورة كلها

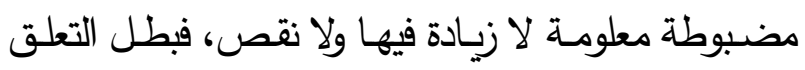
بهذا الفصل ولله تعالى الحمد.

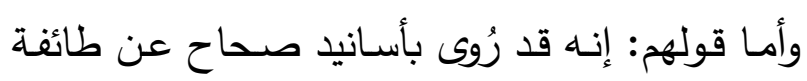
من أصحاب رسول الله كئس ومن التابعين الذين نعظم

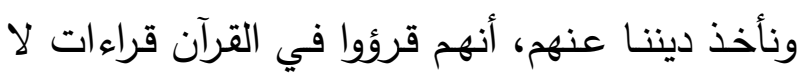

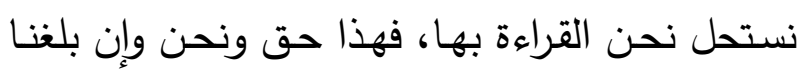

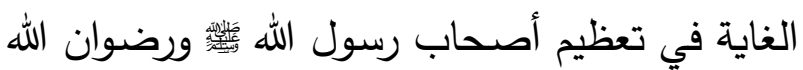
عليهم، وتقربنا إلى الله عز وجل بمحبتهم فلسنا نبعد

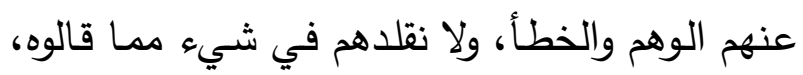

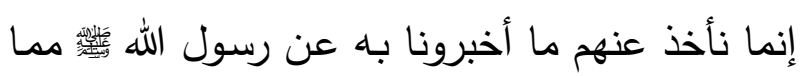

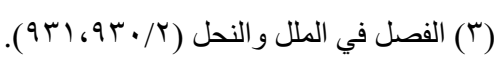

ثم يقول رحمـه الله:" اعلموا أن رسول الله لم يكتم

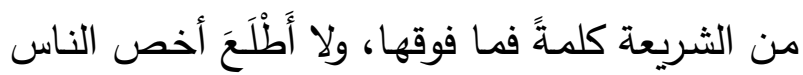

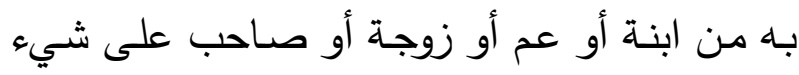

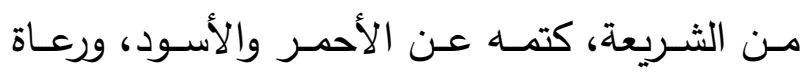

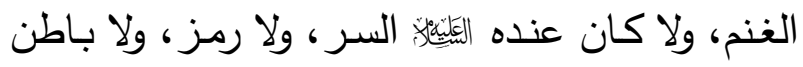
غير ما دعا الناس كلهم إليه، ولو كتمهم شينًا لما ولان

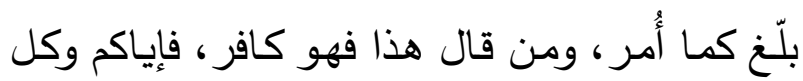

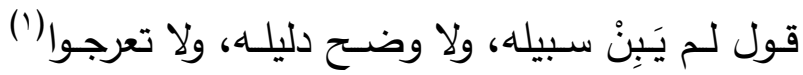

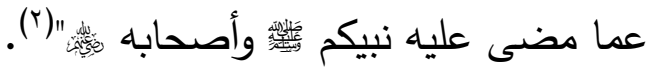
دعوى أننا مختلفون في قراءة كتبانا، وأن هناك قراءة

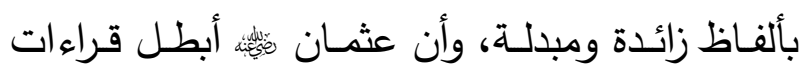

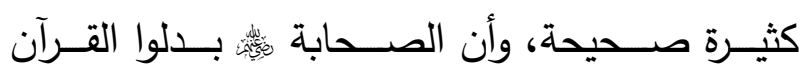

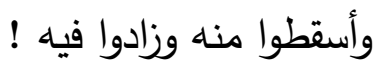
ذكر أبو محمد هذه الثبه من شبهات القوم، فقال:"

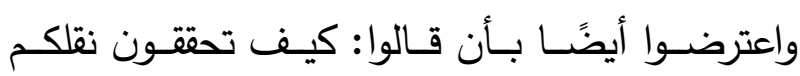
لكتابكم وأنتم مختلفون أشـد الاختلاف في قراءوتكم له؟! وبعضكم يزيد حروفًا كثيرة وبعضكم يسقطها؟!

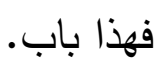
وأيضًا: فإنكم تروون بأسانيد عندكم في غاية الصحة

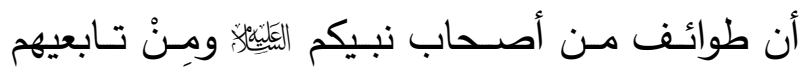
الذين تعظمـون وتأخذون دينكم عنهم قرؤوا القرآن

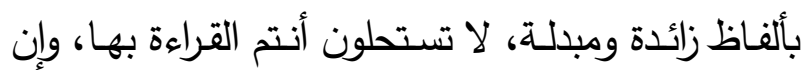
مصحف عبد الله بن مسعود خلاف مصحفكر؟!.

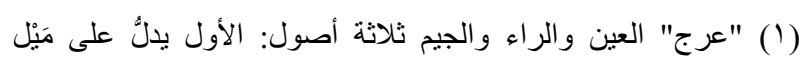

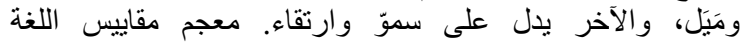

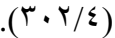

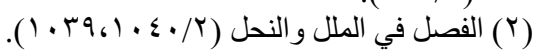


الصبيان والنساء، وكل من دبّ وهبّ. واليمن كلها، وهي في أيامسه مدن وقرى، والبحرين كذلك، وعُمان كذلك، وهي بلاد واسعة مدن وقرى، ومكة والطائف، والمدينة والشام، كلها كذلك، والجزيرة كذلك، ومصر كلهـا كذلك، والكوفـة والبصـرة كذلك، في كل هذه البلاد من المصاحف والقرّاء ما لا يحصي عددهم إلا

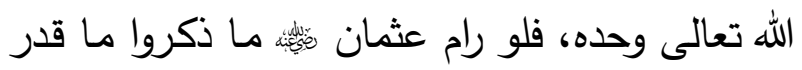
على ذلك أصلاً . وأما قولهم: إنه جمع الناس على مصحف فباطل؛ ما

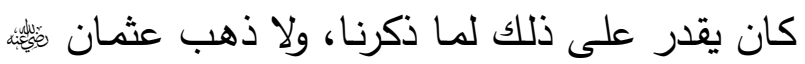
قط إلى جمع الناس على مصحف كتبه، إنما خشي

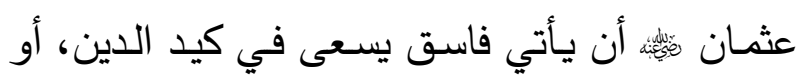
أن يَهِمَ وهم من أهل الخير فيبدل شينًا من المصحف لفي يفعل ذلك عمدًا، وهذا وهمًا، فيكون اختلاف يؤدي إلى الضلال، فكتب مصاحف مجتمعًا عليها، وبعث إلى كل أفق مصـحفًا، لكي إن وهـم واهـم، أو بـدل مبدل رجـع إلى المصـحف المجتمـع عليه، فانكشف الحق وبطل الكيد والوهم. وأما قول من قال أبطل الأحرف الستة فقد كذب من

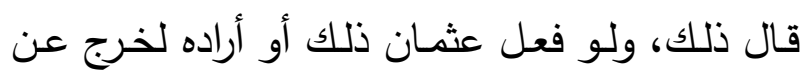
الإسـاملا(Y)، ولمـا مُطِلَ سـاعة، بـل الأحرف السبعة

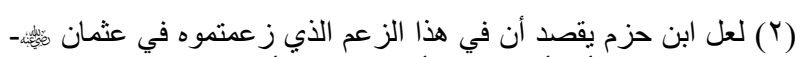

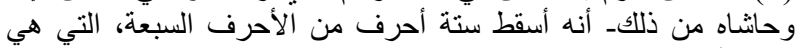

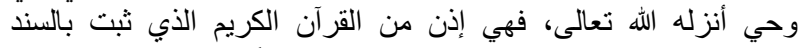

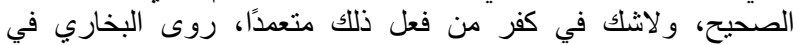

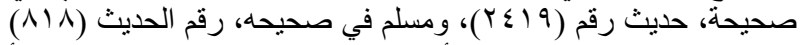

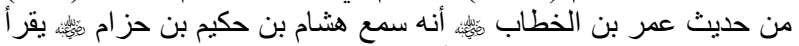

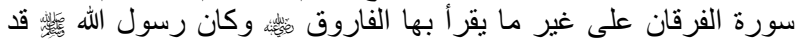

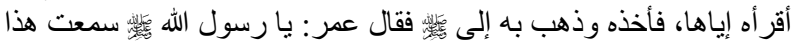

هو عندهم بالمشاهدة والسماع، لما ثبت من عدالتهم وثقتهم وصدقهم. وأما عصمتهم من الخطأ فيما قالوه برأي أو بظن فلا نقول بذلك.... وتلك القراءات التي ذكرتم إنمـا هي موقوفة على الصـاحب أو التابع، فهي ضـرورة وهْمٌ من الصساحب، والوهم لا يعرى منـه أحد بعد الأنبياء عليهم السلام، أو وهم ممن دونه في ذلك.

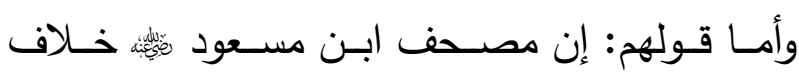
مصحفنا؛ فباطل وكذب وإفك، مصحف ابن مسعود إنمــا فيـهـ قراءتــه بـلا شــك، وقراءتــهـ هـي قـراءة

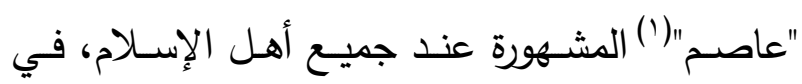
شـرق الأرض وغربها، نقرأ بها كما ذكرنـا كما نقرأ

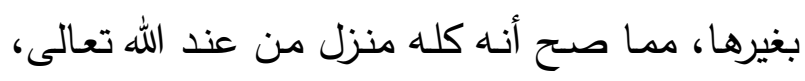
فبطل تعلقهم بهذا والحمد لله رب العالمين. وأمسا قولهم: إن طائفة من علمائنا الذين أخذنا دينتا

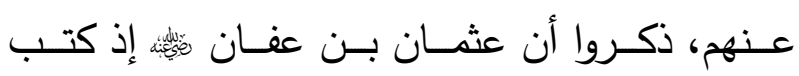
المصحف الذي جمع الناس عليه أسقط ستة أحرف من الأحرف المنزلة واقتصر على حرف منها، فهو مما قلنا. وهو ظن ظنه ذلك القائل أخطأ فيه وليس كما قال، بل كل هذا باطل ببرهان كالشمس، وهو أن

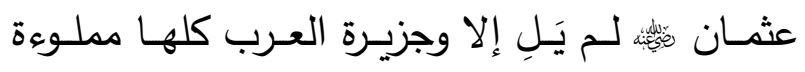
بالمسـلمين، والمصــاحف والمسـاجد والقـراء يُعلمـون

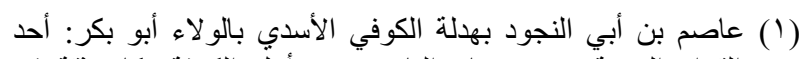

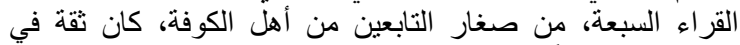

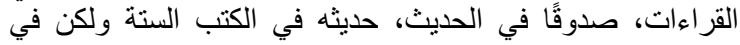

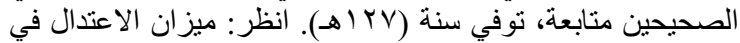

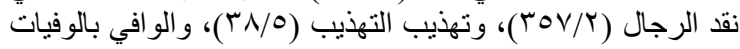
(TYT//7) 
وما رامت غلاة الروافض وأهل الإحاد الكائدون

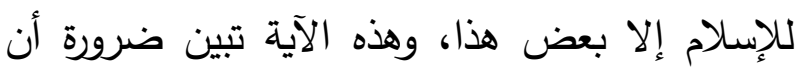
جميع القرآن كما هو من ترتيب حروفه وكلماته وآياته

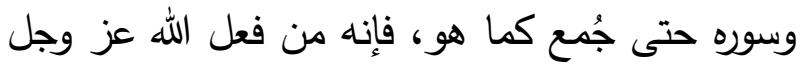

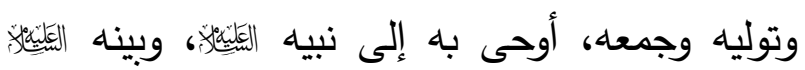

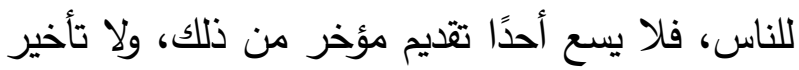

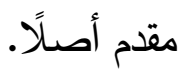
ونحن نبين فعل عثمان لِئة ذلك بيانًا لا يخفى على

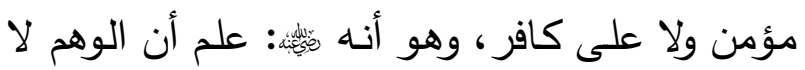

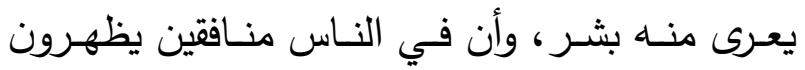

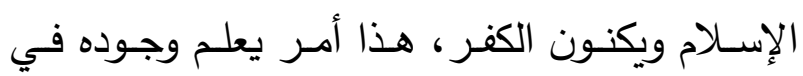

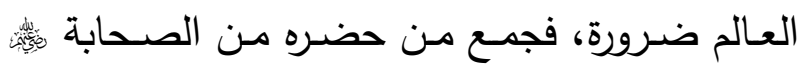

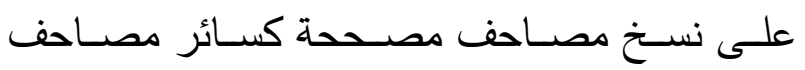
المسلمين ولا فرق، إلا أنها نسخت بحضرة الجماعة فقط، ثم بعث إلى أمصار المسلمين إلى كل مصر

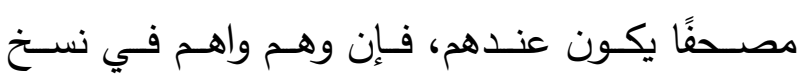
مصحف، وتعمد ملحد تبديل كلمة في المصحف أو وهم واهن في القراءة، رجـع إلى المصـف المشهـور المتفق

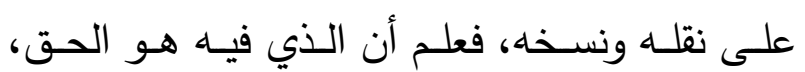
وكيف كان يقدر عثمان على ما ظنه أهل الجهل! والإسلام قد انتشر من خراسان إلى برقة، ومن اليمن

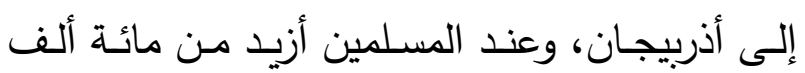

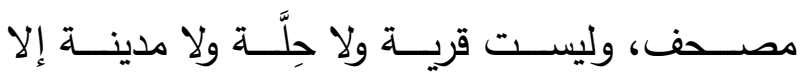
والمعلمون للقرآن موجودون فيها، يعلمونـه من تعلمهـ

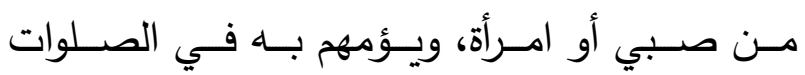

كلهـا موجودة عندنا قائمـة، كمـا كانـت مثبوتـة في

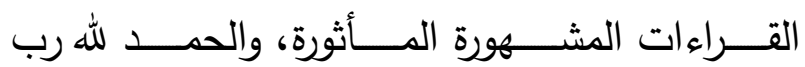
العالمين" ('). وقال ابن حزم أيضًا في دحض هذه الثبهة:" وأما

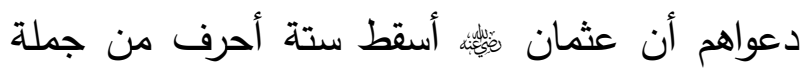
الأحرف السبعة المنزل بها القرآن من عند الله عز ان وجل، فعظيمة من عظائم الإفك والكذب، ويعيذ الله

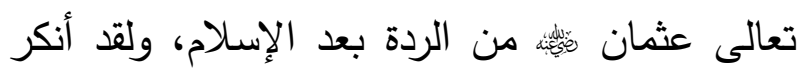

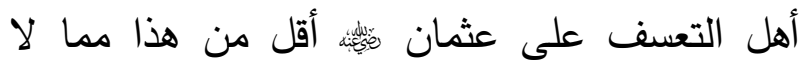

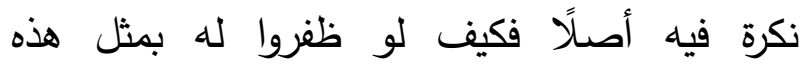
العظيمة، ومعاذ الله من ذلك، وسواء عند كل ذي لهرة عقل إسقاط قراءة أنزلها الله تعالى أو إسقاط آية ولى دماه

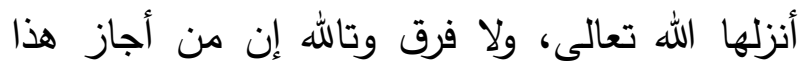

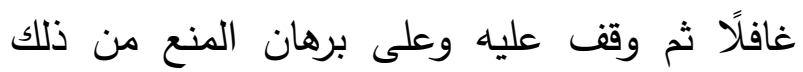
وأصر، فإنه خروج عن الإسلام لا شك فيه؛ لأنه

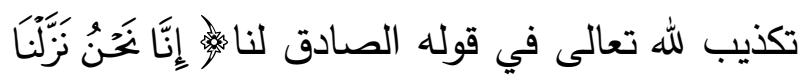

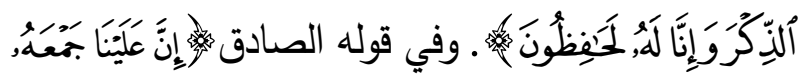

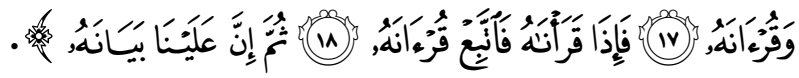
فالكل مأمورون باتباع قرآنه الذي أنزله الله تعالى عليه، وجمعه به، فمن أجاز خلاف ذلك فقد أجاز خلاف الله تعالى، وهذه ردة صحيحة لا مرية فيها،

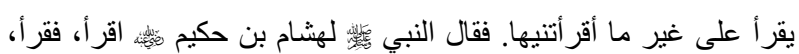

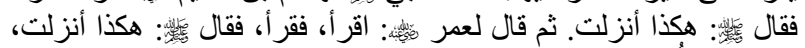

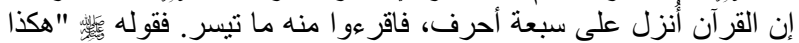

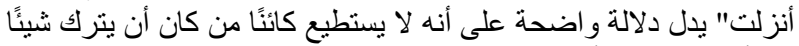

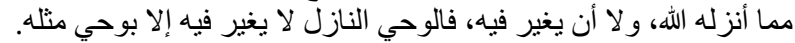

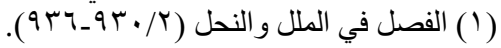


سمع زيد بن ثابت قال: فقدت(ب) آية من الأحزاب

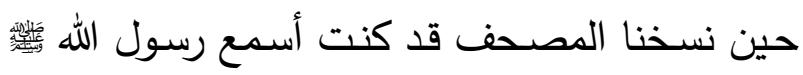
يقرأ بها، فالتمسناها فوجدناها مـع خزيمـة بن ثابــ

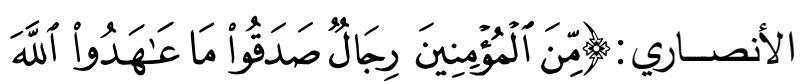

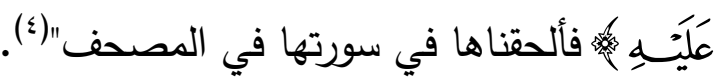

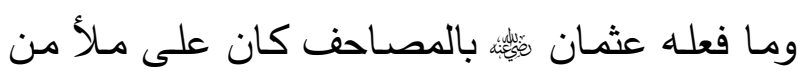

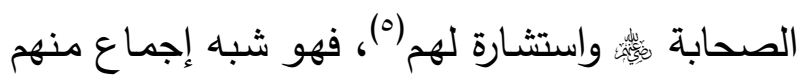

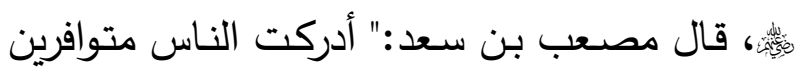

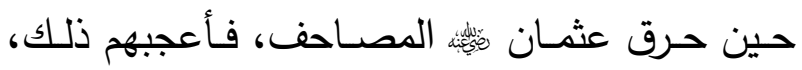
وقال: لم ينكر ذلك منهم أحد"(؟). وقال سويد بن غفلة:" والله لا أحدثكم إلا شينًا سمعته

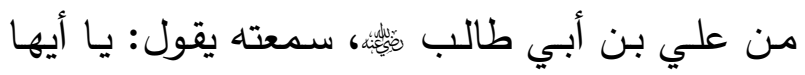

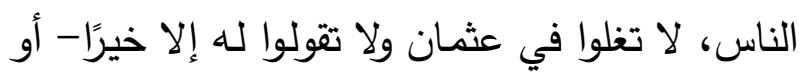

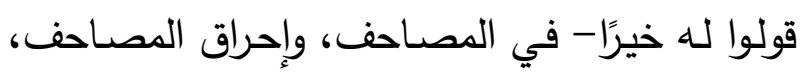

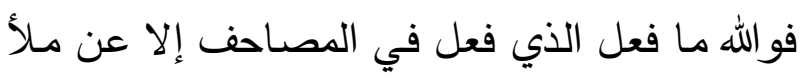

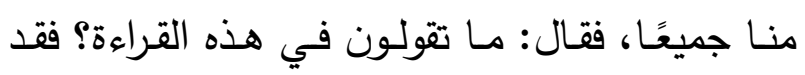

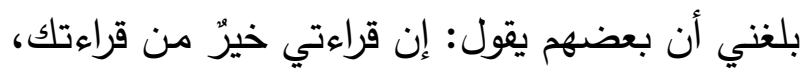

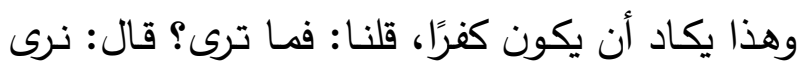

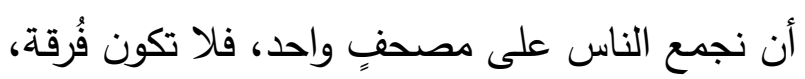

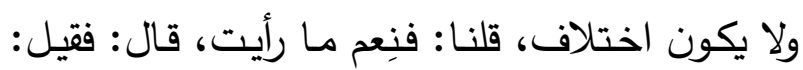

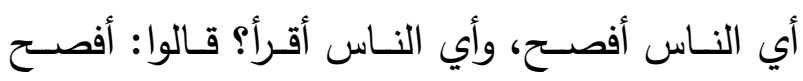

(T) فيه دلالة على أن زيد بن ثابت هِئية كان يعرف الآية ولكنه لم يجدها

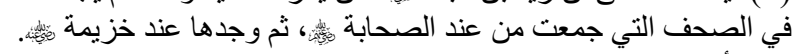

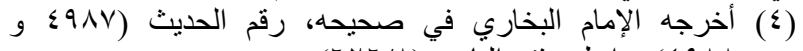

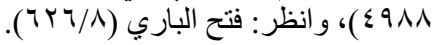

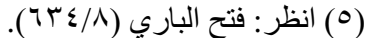

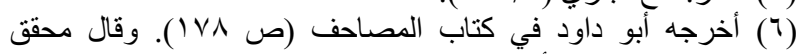
الكتاب عن سند الأثر: إسناده صحيح.

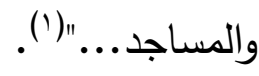

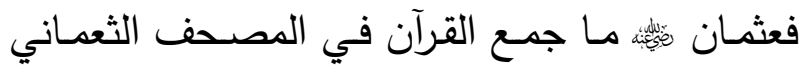

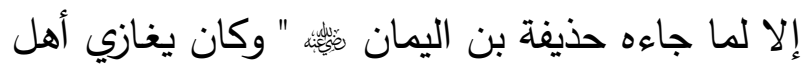

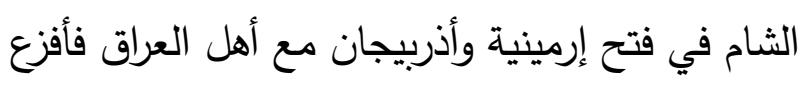

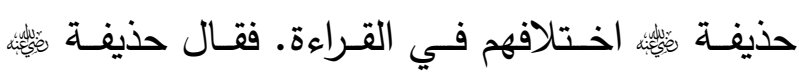

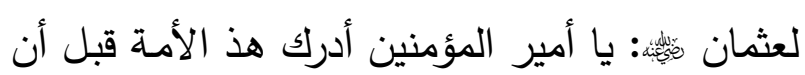

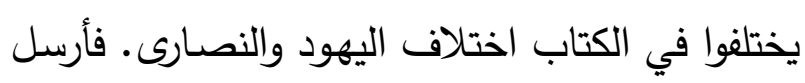
عثمان إلى حفصة أن أرسلي إلينا بالصحف ننسخها

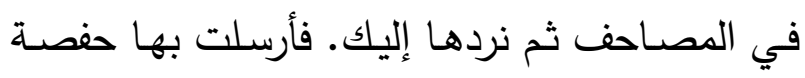
إلى عثمان، فأمر زيد بن ثابت وعبد الله بن الزبير

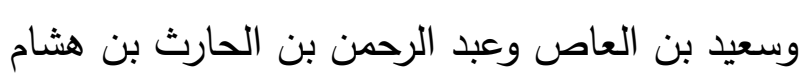

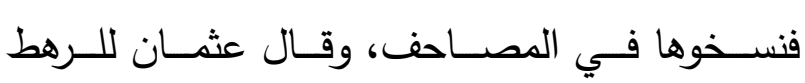
القرشيين الثلاثة: إذا اختلفتم أنتم وزيد بن ثابت في في في في في

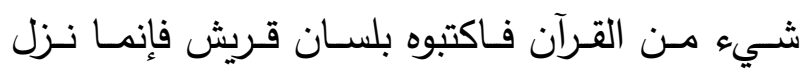

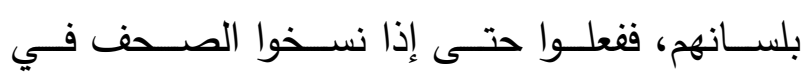
المصـاحف رد عثــان الصـف إلى حفصـة وأرسل

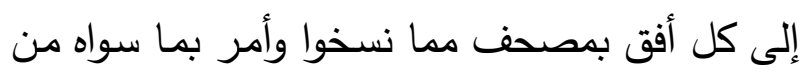

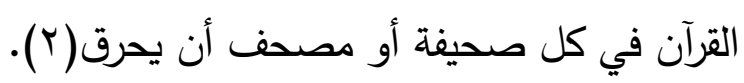
قال ابن شهاب: وأخبرني خارجة بن زيد بن ثابت،

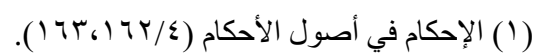

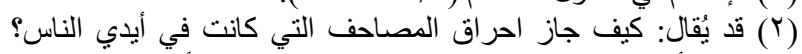

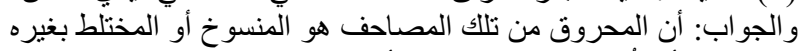

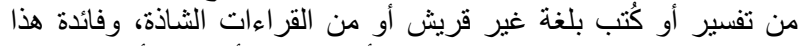

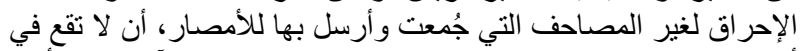

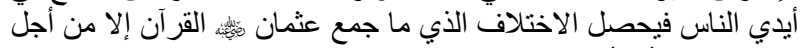

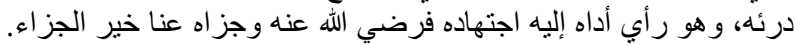

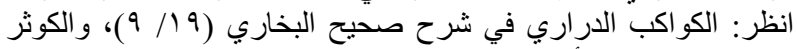

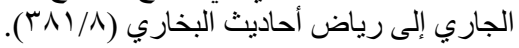


دفعهم لهذا الكفر أنهم مـا وجدوا في القرآن الكريم الموجود بين يدي الناس ما يقنعون به أتباعهم، لخلوه من النص على أئمتهم وعقائدهم. خامسًا: أول كتاب ذُكرت فيه هذه الفرية العظيمة هو الذي يسميه الثيعة أبجد الثيعة، وهو كتاب "سليم بن قيس"، الذي كثف بعض شيوخهم عن أمره، وأنه موضوع، ومؤلفه مجهول.

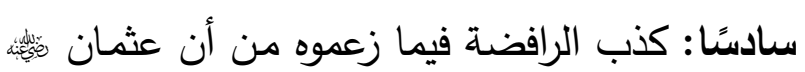
أسقط ستة أحرف من الأحرف السبعة.

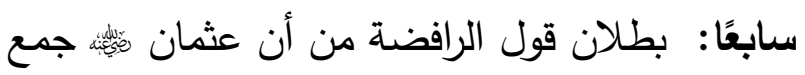

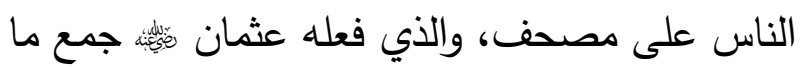
كان مكتوبًا في الصحف التي كانت في أيدي الناس في مصحف واحد.

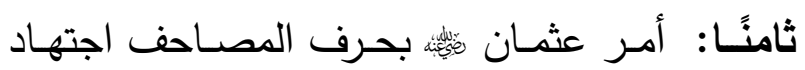

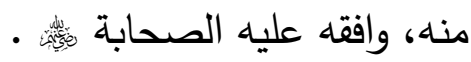

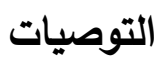

أوصـي إخـواني مـن طلبــة العـــم بـإبراز دور أئعــــ

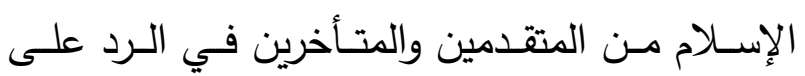
أباطيل وضـلالات الرافضـة، التي أصبحت تعج بها الفضائيات، ويتناقلها الناس.

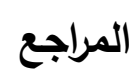

ا ـ ابن حزم حياته وعصره آراؤه وفقهه، محمد أبو

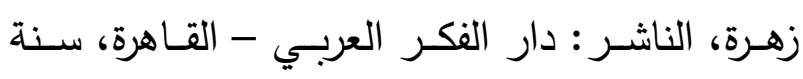

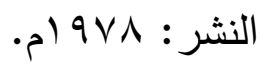

النـاس سـعيد بـن العـاص، وأقرؤهم زيــــــن ثابــ،

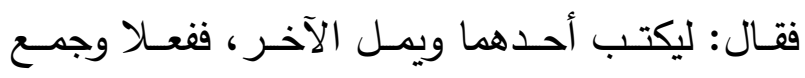
الناس على مصحف، قال: قال علي: والله لو وُلّيت

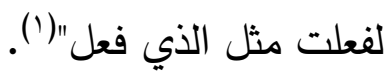

\section{الخاتمة}

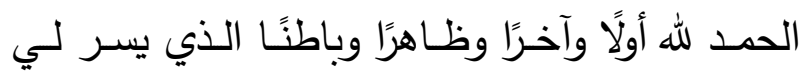
إتمام هذا البحث، فما كان فيـه من صواب فمن الله وطن

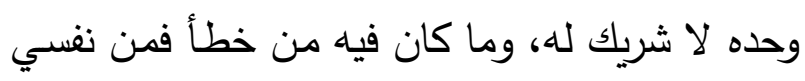

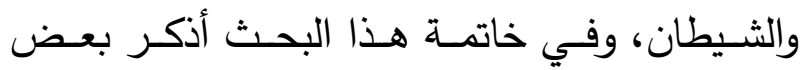
النتائج التي خلصت إليها، وهي: أولًا: أن النصرة والمتابعة المتمثلة في المعنى اللغوي

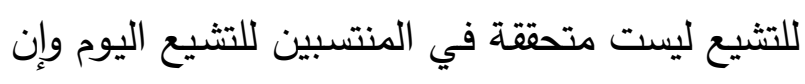
ادعو ذلك زورًا وبهتانًا. ثانيًا: التشيع خليط من مذاهب الفرس والروم واليونان والنصارى واليهود وغيرهم. ثالثًّا: كانـت بدايـة إدخـال هـذه البـدـع والضــلالات

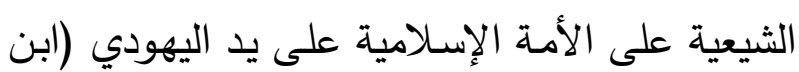
سبأ) وأتباعه.

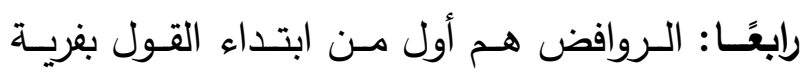
"تحريف القرآن الكريم"، في القرن الثاني، ونسبت إئى إلى إنى هشام بـن الحكم، وشيطان الطاق، ولم يعرف أهل

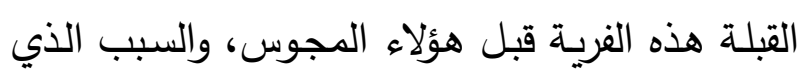
(1) أخرجه أبو داود في كتاب المصاحف، باب: جمع عثمان رحمةُ الله

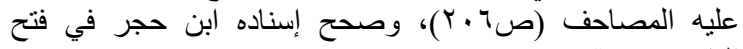

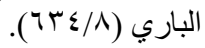


A. تاريخ بغداد، لأبي بكر أحمد بن علي بن ثابت الخطيـب البغـدادي، تحقيـق: الـدكتور بشـار عـواد معروف، الناشـر : دار الغرب الإسـلامي - بيـروت،

$$
\text { الطبعة: الأولى، بr اهـ. }
$$

9. تذكرة الحفاظ، لشمس الدين أبو عبد الله محمد بن

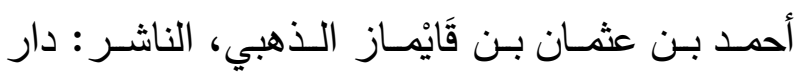

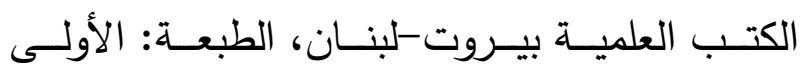

. $1 \leqslant 19$

• ا. التعديل والتجريح لــن خـرج عنـه البخـاري في

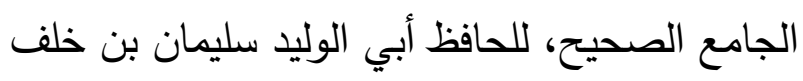
بن سعد ابن أيوب الباجي المالكي، دراسة وتحقيق:

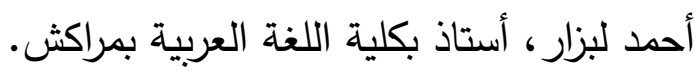
ا الـالتعريفـات، علـي بـن محمـد بـن علـي الـزين الشريف الجرجاني، تحقيق: ضبطه وصححه جماعة

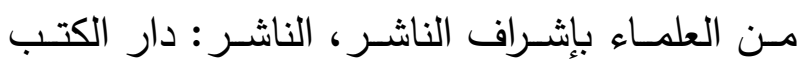
العلمية بيروت -لبنان، الطبعة: الأولى ؟ +ــ اله. r ا.تمهيد الأوائل في تلخيص الدلائل، لأبي بكر محمد بـن الطيب بـن محمد بـن جعفر بـن القاسـ

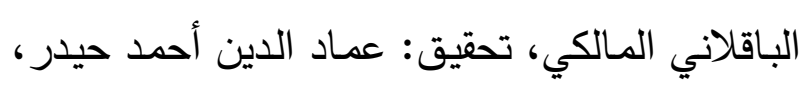

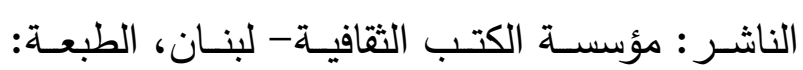

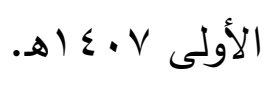

با ا.تهذيب التهذيب، لأبي الفضل أحمد بن علي بن حجر العسـقلاني، الناشــر : مطبعـة دائرة المعـارف النظامية- الهند، الطبعة: الأولى بr آهـ. r. الإحكام في أصول الأحكام، لأبي محمد علي

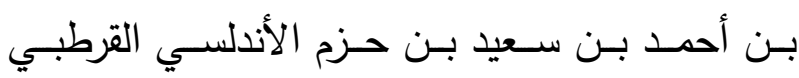

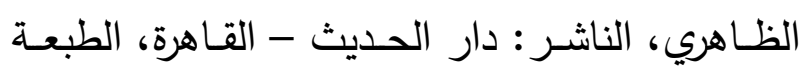

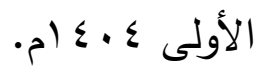
r. أصول مذهب الإمامية الإثني عشرية- عرض ونقد، للـدكتور ناصـر بـن عبدالله القفـاري، الطبعـة الثانية 0 إ اهـ. ع. الأعـلام، خير الدين بن محمود بن محمد بن

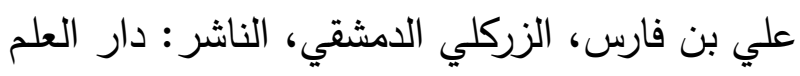

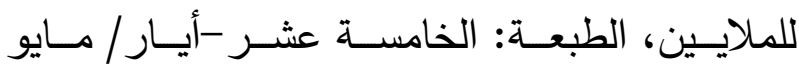

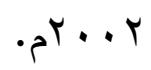

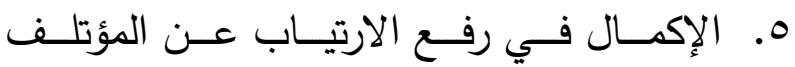
والمختلف في الأسماء والكنى والأنساب، سعد الملك الأكئ

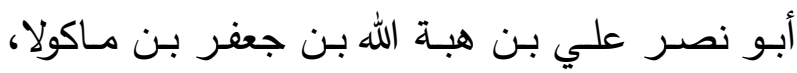
الناشر : دار الكتب العلمية -بيروت-لبنان، الطبعة:

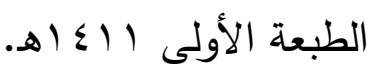
7. الأنسـاب، عبد الكريم بـن محمــ بـن منصـور

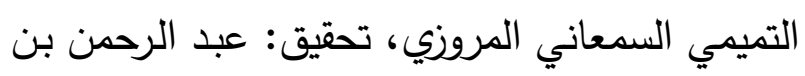

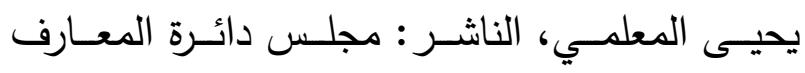

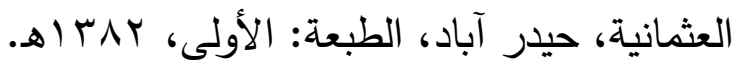
V. ت تـاريخ الإســلام وَوَفيـات المشــاهير وَالأعـلام، شمس الدين أبو عبد الله محمد بن أحمد بن عثمان

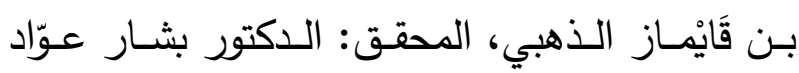

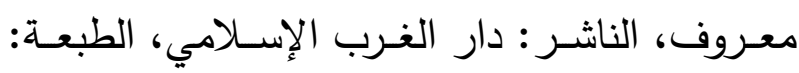

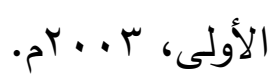


اعتنى به: علي بن محمد العمران، الناشر : دار عالم الفوائد للنشر والتوزيع - السعودية. 9 ا ـسـير أعـلام النبلاء، لشـمس الدين أبو عبد الله

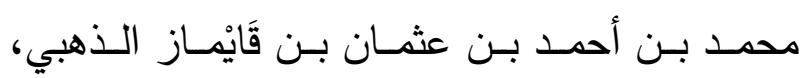
المحقـق : مجموعـة مـن المحققـين بإشـراف الثـيخ شعيب الأرناؤوط، الناشر : مؤسسة الرسالة، الطبعة:

الثالثة 0 • ع اهـ.

•r. شذرات الذهب في أخبار من ذهب، عبد الحي بن أحمد بن محمد ابن العماد العَكري الحنبلي، أبو الفلاح، حققه: محمود الأرناؤوط، خرج أحاديثه: عبد القادر الأرنـاؤوط، الناشـر : دار ابن كثير، دمشـق بيروت، الطبعة: الأولى، 7 . ع اهـ .

ا Y. الثـيعة والسـنة، إحسـان إلهـي ظهيـر، الناشـر : إدارة ترجمـان الســنة، لاهـور - باكسـتان، الطبعـة:

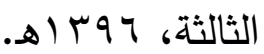

r...طوق الحمامـة في الألُفة والألأَّف، لأبي محمد علي بن أحمد بن سعيد بن حزم الأندلسي القرطبي الظـاهري، تحقيـق: إحســان عبــاس، دار النشـر : المؤسسـة العربيـة للدراسـات والنشـر ، بيروت- لبنـان،

$$
\text { الطبعة: الثانية - } 9 \text { ام. }
$$

rr . عبـد الله بـن سـبأ وأثره في إحـداث الفتــة في صدر الإسـلام، سليمان بن حمد العودة، الناشر : دار

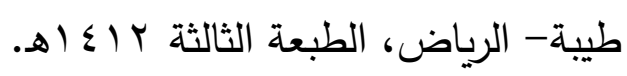

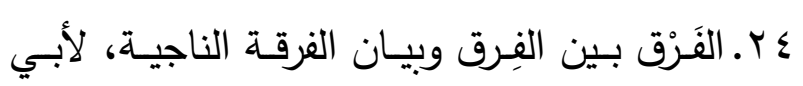
منصور عبد القاهر بن طاهر بن محمد بن عبد الله
ء ا ـ الجامع لأحكام القرآن ، لأبي عبد الله محمد بن أحمد القرطبي، تحقيق: سمير البخاري، الناشر : دار عـالم الكتب، الريـاض- المملكـة العربيـة السـودية،

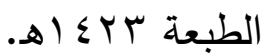

1 ـ جذوة المقتبس في ذكر ولاة الأندلس، محمد بن فتوح بن عبد الله بن فتوح بن حميد الأزدي الميورقي الحَمِيدي أبو عبد الله بن أبي نصـر، الناشر : الدار المصـريـة للتـأليف والنشـر - القـاهرة، عـام النشـر : . ) 977

7 1 ـ الخطوط العريضـة للأسس التي قام عليها دين الشيعة الإمامية الاثتي عشرية، محب الدين بن أبي الفتح بن عبد القادر بن صـالح بن عبد الرحيم بن

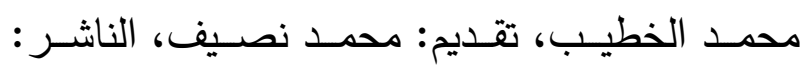
بدون. V إ.رسائل ابن حزم الأندلسي، لأبي محمد علي بن أحمد بن سعيد بن حزم الأندلسي القرطبي الظاهري، تحقيـق : إحسـان عبـاس، الناشـر : المؤسســة العربيـة للدراســات والنشــر ، بيــروت - لبنــان، الطبعـــة:

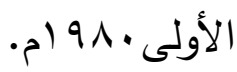

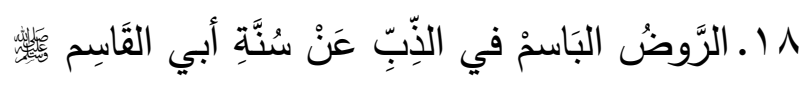
(وعليـه حـواشٍ لجماعـةٍ مـن العلمـاء مـنهم الأميـر الصّنعاني)، لابن الوزير ، محمد بن إبراهيم بن علي بن المرتضـى بن المفضل الحسني القاسمي، تقديم:

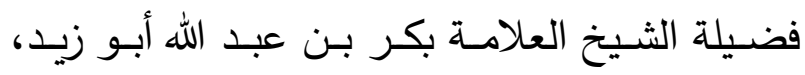


•r.لسان الميزان، لأبي الفضل أحمد بن علي بن

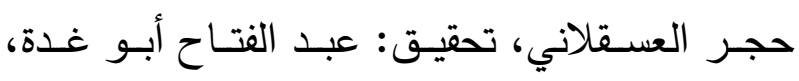

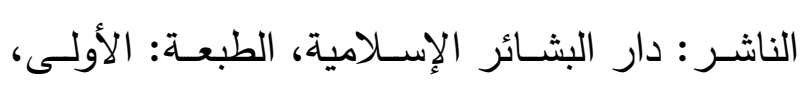
. r. r t r

اس. مجموع الفتاوى، لتقي الدين أبو العباس أحمد

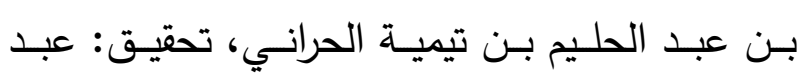

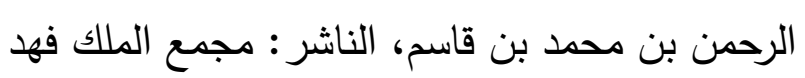

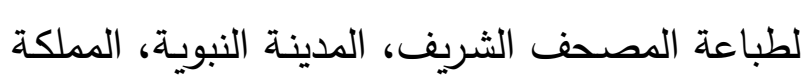
العربية السعودية، عام النشر : 71 إ؛ اله. rr. المحلى بالآثار ،لأبي محمد علي بن أحمد بن سعيد بن حزم الأندلسي القرطبي الظاهري، الناشر :

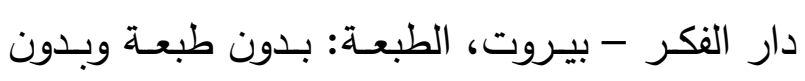
تاريخ. سب. المعتمد في أصـول الدين، للقاضـي أبي يعلى

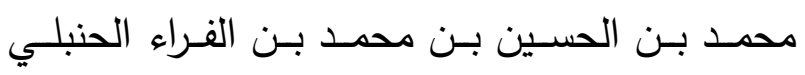

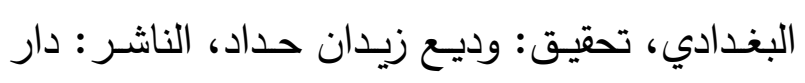

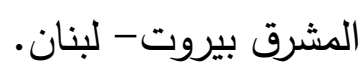
ع ז.معجم البلدان، شهاب الدين أبو عبد الله ياقوت

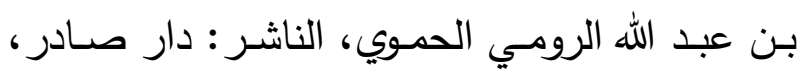
بيروت، الطبعة: الثانية 990 ام.

هب.مقـالات الإسـلاميين واختلاف المصلين، لأبسي الحسن علي بن إسماعيل بن أبي موسى الأشعري، عنى بتصـحيحه: هلموت ريتر ، الناشـر : دار فرانز
البغدادي التميمسي الأسفراييني، الناشـر : دار الآفـاق الجديدة - بيروت، الطبعة: الثانية 9VV ام. Or. الفصل في الملل والأهواء والنحل، لأبي محمد علي بن أحمد بن سعيد بن حزم الأندلسي القرطبي

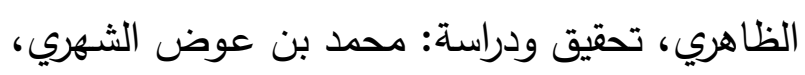

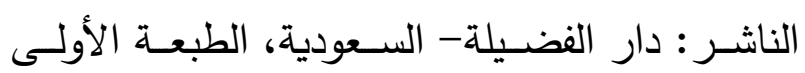
هـ أه . بr. الفهرسـ، لأبسي الفـرج محمد بـن إسـاق بـن محمد الوراق البغدادي المعروف بابن النديم، تحقيق:

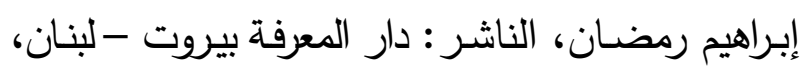
الطبعة: الثانية Vإ الهـ لاثن rV

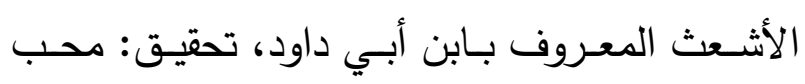

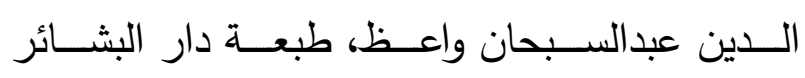

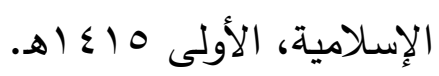
^ץ. الكواكب الدراري في شرح صحيح البخاري، لـ:

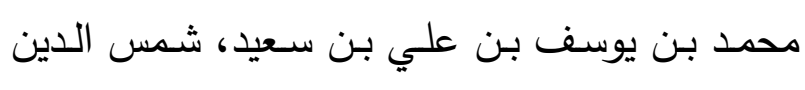

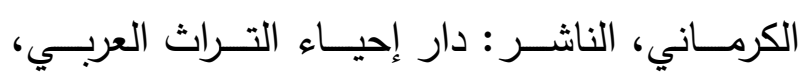

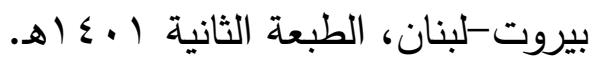
و ا. الكـوثر الجـاري إلى ريـاض أحاديث البخـاري،

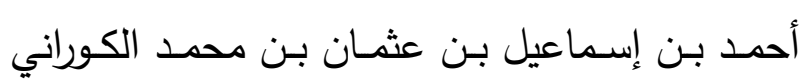

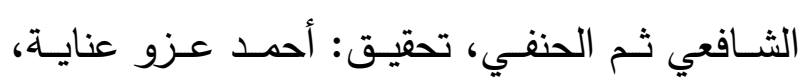

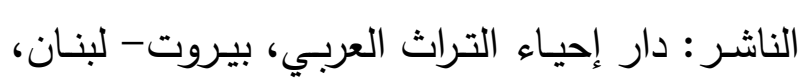

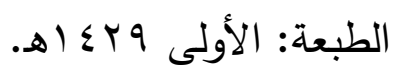


^ץ. ميزان الاعتدال في نقد الرجال، محمد بن أحمد الذهبي، تحقيق: علي محمد البجاوي، الناشر : دار المعرفة للطباعـة والنشـر، بيروت - لبنـان، الطبعة:

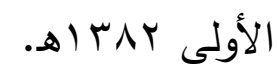

qr. الوافي بالوفيات، صلاح الدين خليل بن أيبك بن عبد الله الصفدي، تحقيق: أحمد الأرنـاؤوط وتركي مصطفى، الناشر : دار إحياء التراث- بيروت، سنة

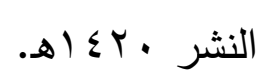

• ـ ـ وفيات الأعيان وأنباء أبناء الزمان، لأبي العباس

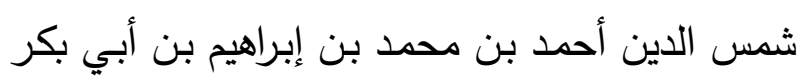

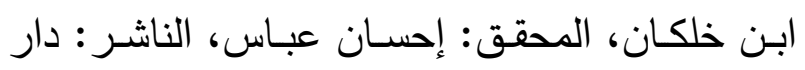

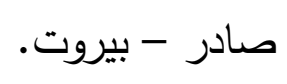

شـتايز ، بمدينـة فيسبادن (ألمانيـا)، الطبعـة: الثالثة، .ه) $\leqslant \ldots$ جس. الملل والنحل، محمد بن عبد الكريم بن أبي بكر

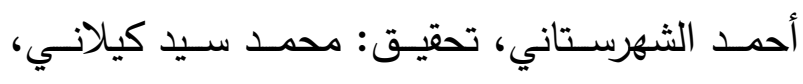

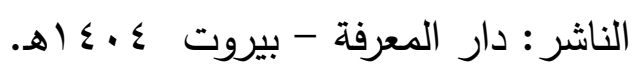
TV. موجز دائرة المعارف الإسلامية، تحرير : م. ت.

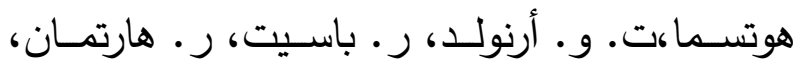
الأجزاء (أ) إلى (ع): إعداد وتحريـر : إبـراهيم زكي لهي لهي

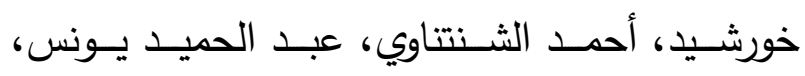
الأجزاء من (ع) إلى (ي): ترجمة: نخبة من أساتذة

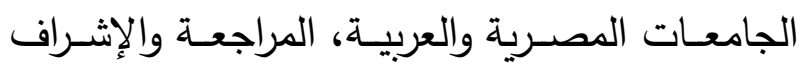

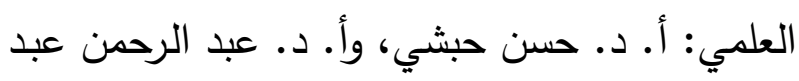

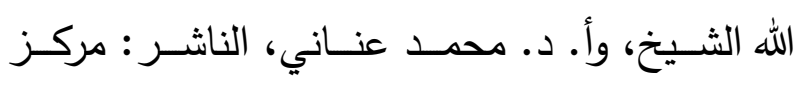

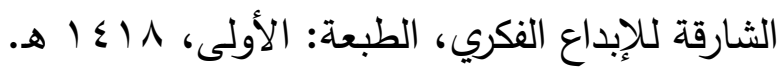




\title{
The position of Imam Ibn Hazm Al-Andalusi on suspicion of distorting the Koran when Shiites
}

\author{
Fahd bin Mohammed bin Abdulrahman Al Qurashi \\ Associate Professor of Creed, Department of Creed \\ Umm Al Qura University
}

Preface: It was defined by Ibn Hazm and Shiites and the concept of Shiites has.

Research in the first: the emergence of Shiism and its causes Search for: Ibn Hazm packages of suspicion of distortion of the Koran.

Then the conclusion: the most important results. 